\title{
الإنسان القرآني: دراسة مقارنة بين خصائص الإنسان وصورته في الاجتهاد الإسلامي والوؤية الغربية
}

\section{عبد القادر عبد العالي}

$$
\begin{aligned}
& \text { الملخص }
\end{aligned}
$$

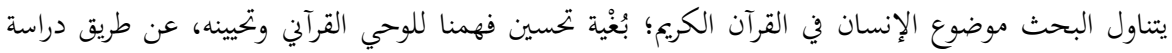

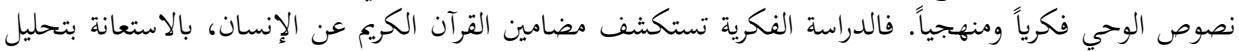

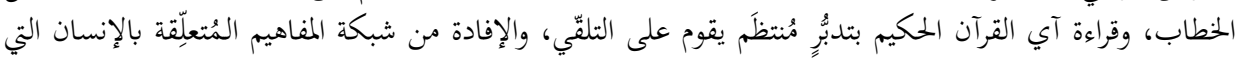

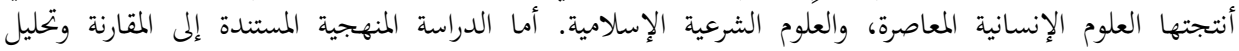

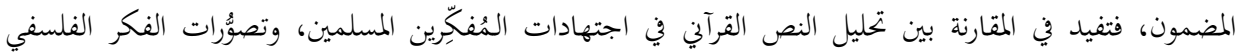

$$
\begin{aligned}
& \text { المعاصر. }
\end{aligned}
$$

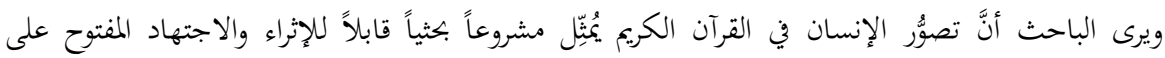

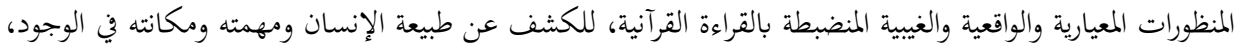

$$
\begin{aligned}
& \text { ويُسبهم في بناء مفهومنا عن إنسان القرآن. } \\
& \text { الكلمات المفتاحية: الإنسان في القرآن الكريم، الإنسان في الفكر المعاصر، الفطرة، المذهب الإنساني. }
\end{aligned}
$$

\section{Quranic Man: A Comparative Study of the Characteristics of Man and his Image between Islamic Jurisprudence and Western Perspective.}

\section{Abdelkader Abdelali}

\section{Abstract}

This paper deals with the topic of Man in the Holy Quran in order to improve and revive our understanding of the Quranic revelation, in content and methodology. Through the study of the content, using discourse analysis, systematic contemplation and making use of network of concepts in contemporary human sciences and Shariah sciences, we would discover how the Holy Quran presents Man. Through the methodological study by using comparative methods and content analysis, we would compare the analysis of Quranic text as perceived by Muslim scholars, with contemporary philosophical thought.

The researcher believes that concept of human in the Holy Quran is considered a research project capable of enrichment and open to diligent efforts of normative, realistic perspectives guided by the Quranic concept of the human nature, position and mission in the world. This would enhance our understanding of Man and contribute to building our concept of Homo-Quranicus.

Keywords: Man in the Quran, Human concept in Contemporary Thought, Human instinct, Humanism.

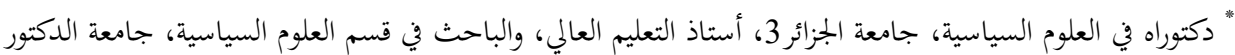

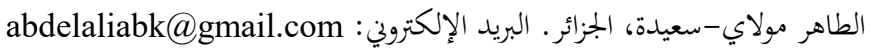

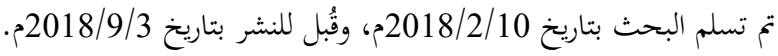




\section{مقدمة:}

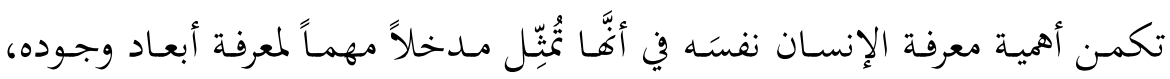

والقدرات والإمكانات المتوافرة لديـ في تطوير تلك الأبعاد. فهذا النوع مـن المعرفة هـو

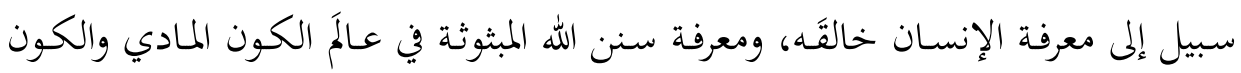

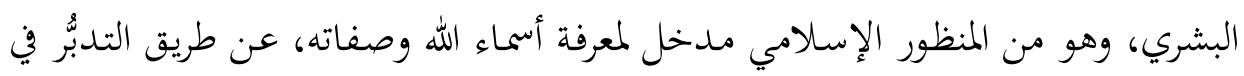
أدلة العناية والرعاية، التي قد يُهمِلها التفكير وَفق الطريقة الوضعية اللادينية.1 ويهدف هذا البحث إلى دراسة محتوى القرآن الكريم دراسة منهجية، تعرض لمدلول الإنسان، وموقعه في الكون، ودوره في نشر رسالة التغيير المنوطة به. وهذه بعض الأسئلة المُلِحَّة التي تبحث عن إجابات شافية ونحن نقارب هذا الموضوع من زاوية مفاهيمية: ما

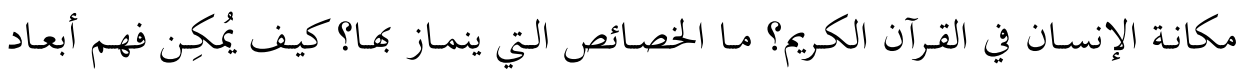

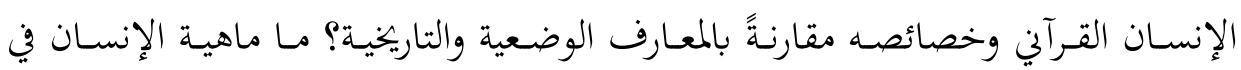
القرآن الكريع؟ كيف نفهم الإنسان القرآي؟ هل نستطيع تناول مسألة الإنسان في القرآن آلـان

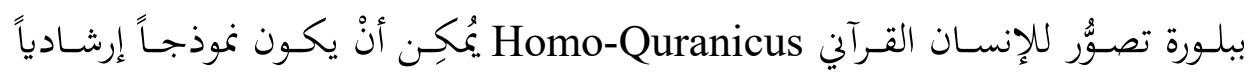

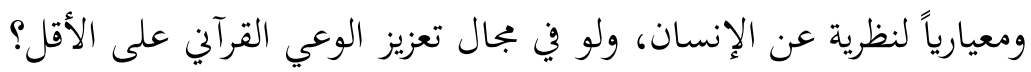

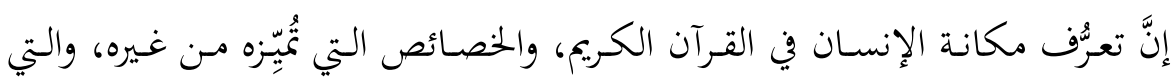

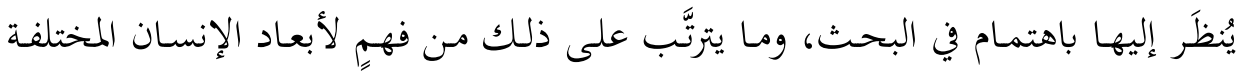

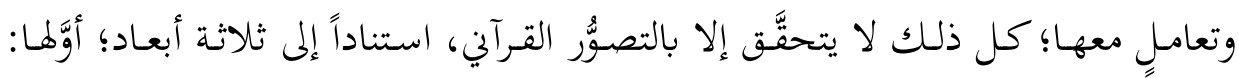

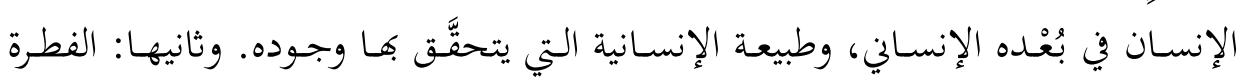

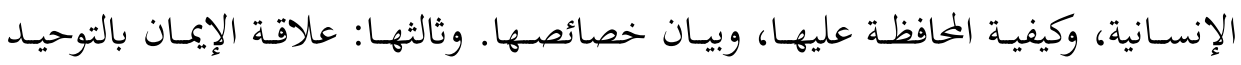
بوصفها نوعاً خاصاً من الدِّين والتديُّن، قد يُحافِظ على فطرة الإنسان وإنسانيته.

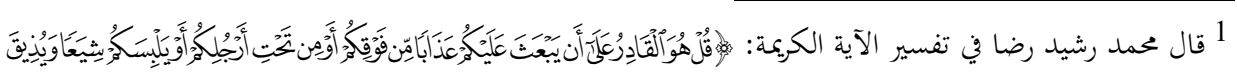

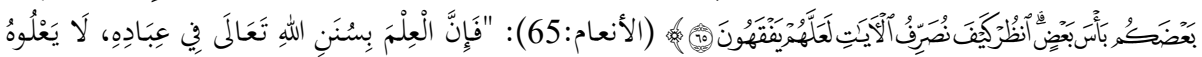

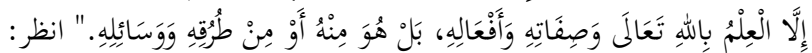

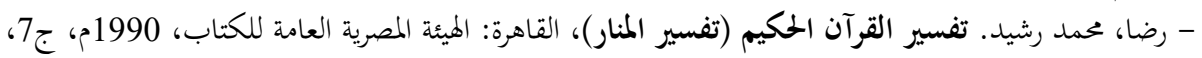




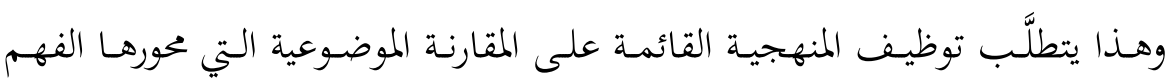

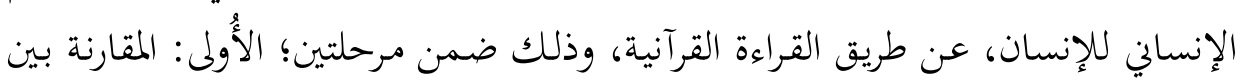

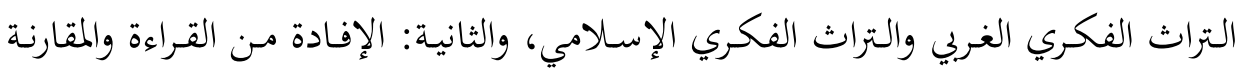

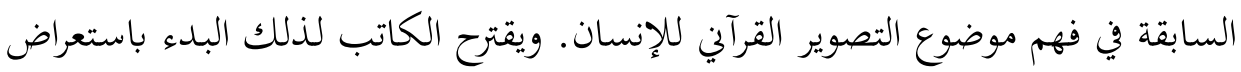

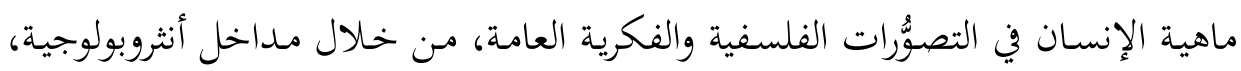

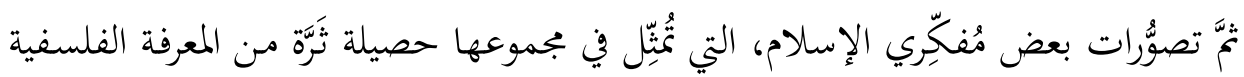

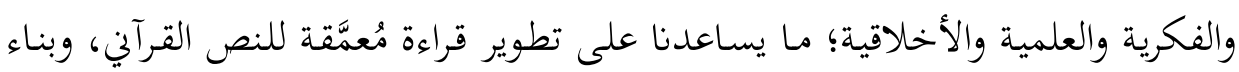

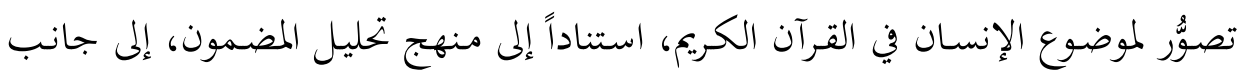

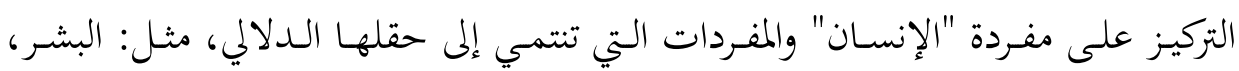

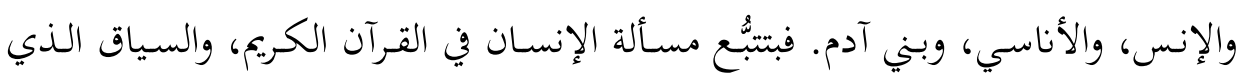

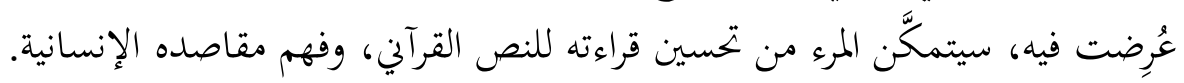

أولاً: مفهوم "الإنسان" في الفلسفة الغربية وتصوُّراتما

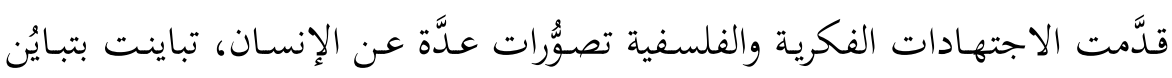

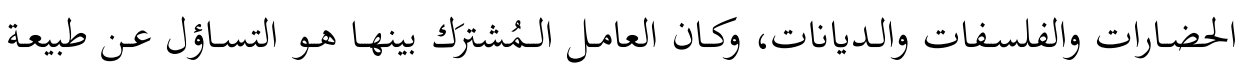

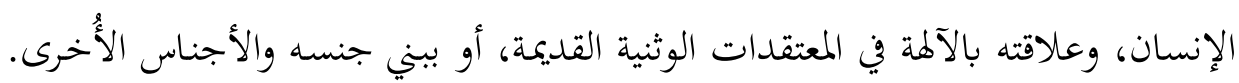

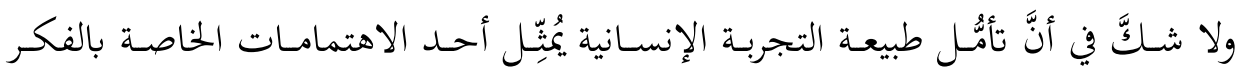

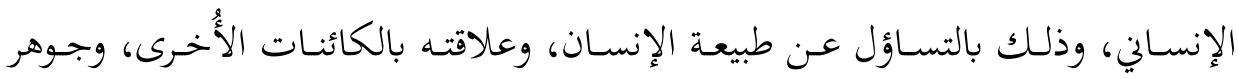

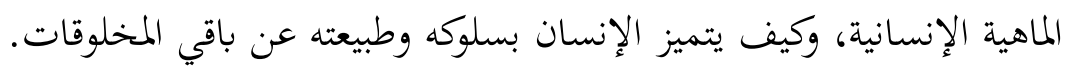

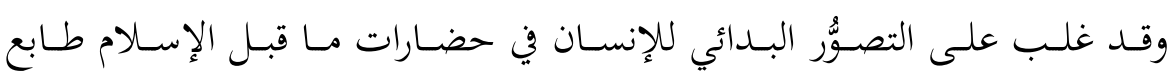

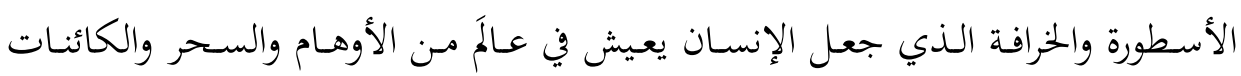

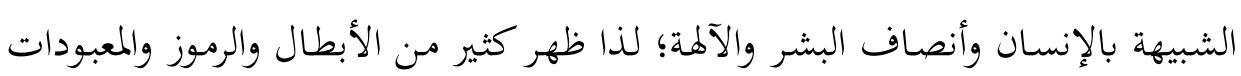

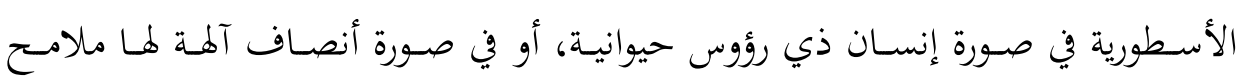

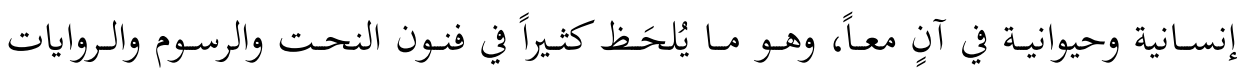
والأساطير، مثل: ملحمة هوميروس، وملحمة جلجامش، وغيرهما من أساطير الأوَّلينَ. 
تمََّّ خطا الوعي البشري خطوات راسخة في تصوُّر الإنسان لنفسه، حين أخذ ينفصل التاريخ عن الأسطورة، وبدأت تظهر معالم الحضارة القائمة على المعرفة التجريبية والتأمُّلية

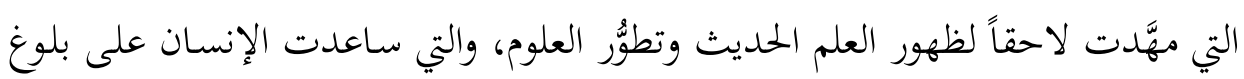

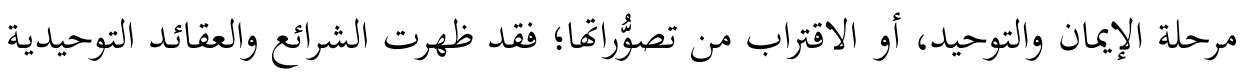

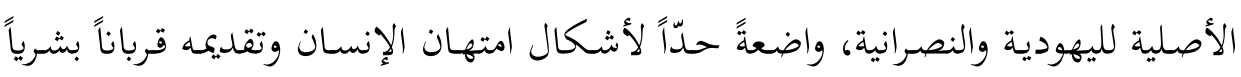

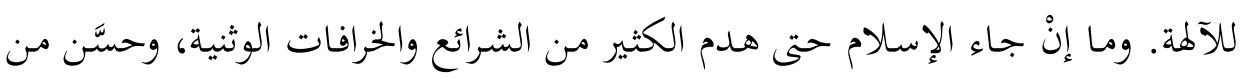

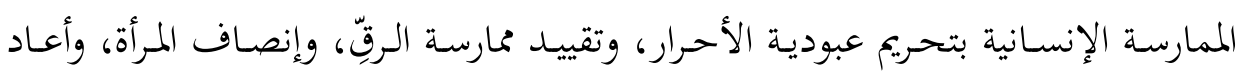

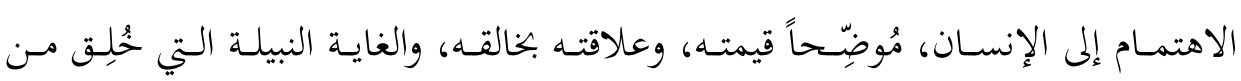
أجلها. وقد استفاد الغرب من التراث الفلسفي والعلمي الذي خلَّفه المُسلِمون، وغملوا من

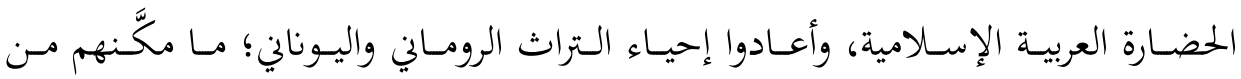
النهوض حضارياً وثقافياً وعلمياً. وكان من أبرز الموضوعات التي شغلت الفكراء الإدرات الإنساني

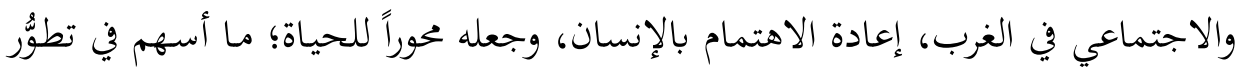

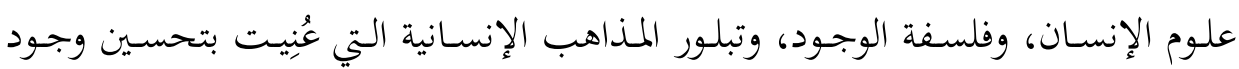

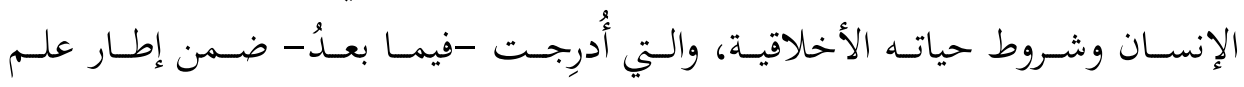

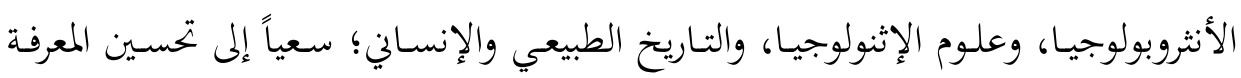
بالإنسان. وتُعَدُّ محاولة نمذجة السلوك الإنساني من الوسائل الفكرية لتنظيم المعارف التي تُعنى

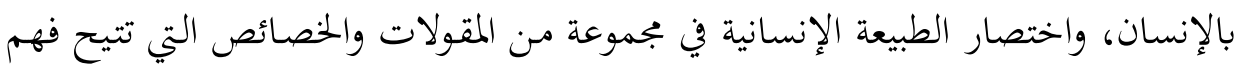

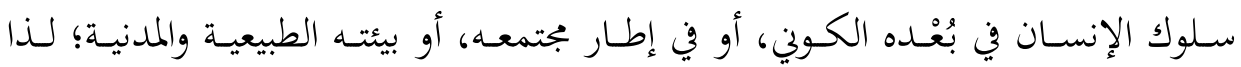

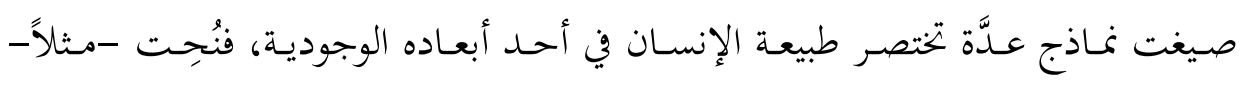
العديد من المصطلحات السائدة في الفلسفة والعلوم المعاصرة، للتعريف بسلوك الإنسانسان إنسان النموذجي، من قبيل: الإنسان الاقتصادي Homo Economicus، و والإنسان الصانع

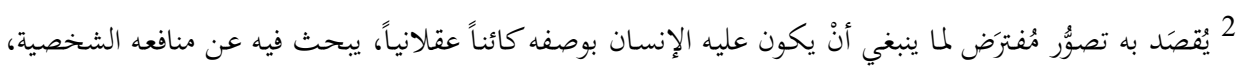
عن طريق تعظيم المنافع والمكاسب. 


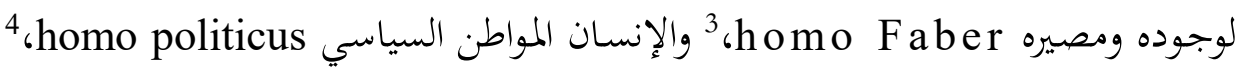

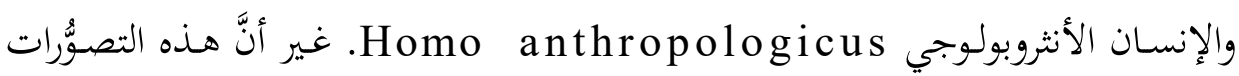

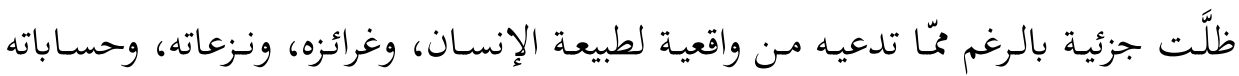
العقلانية، وخصائصه الجوهرية، وسلوكه النمطي الذي يتسم بالكونية.

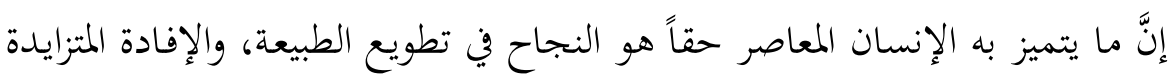

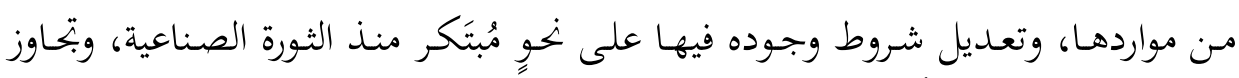

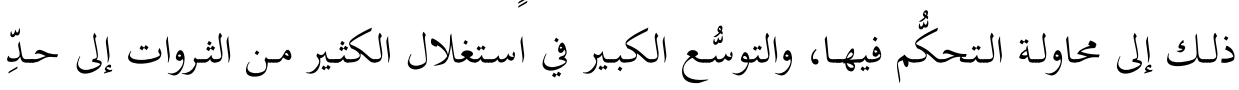

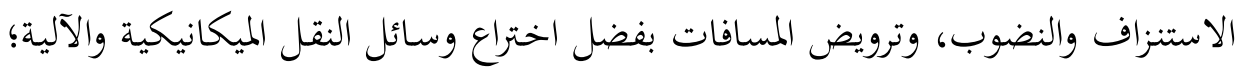

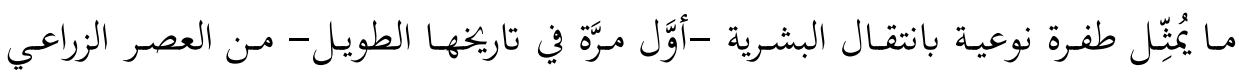

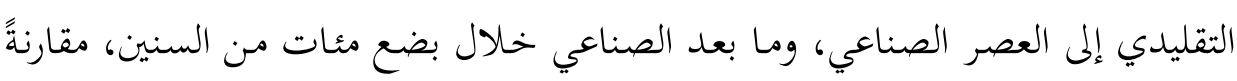
بآلاف السنين من الحضارة الزراعية، وعشرات آلاف السنين من العصور الحجرية.

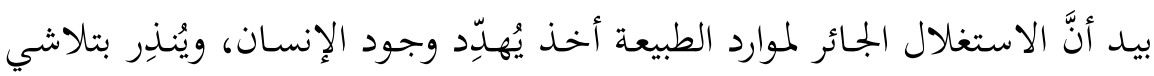

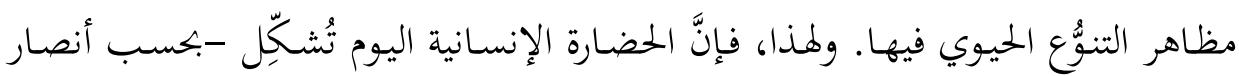

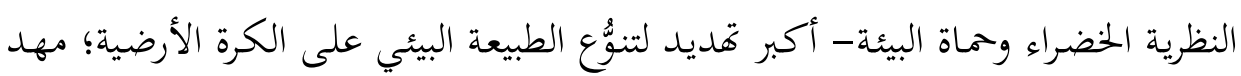

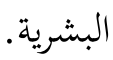

\section{1. - 1 الإنسان الأنثروبولوجي والبيولوجي:}

اهتمَّت دراسات الأنثروبولوجيا وعلم البيولوجيا التطورية بتناول مسألة تطوُّر الإنسان الإنسان

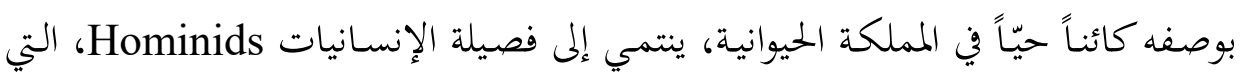

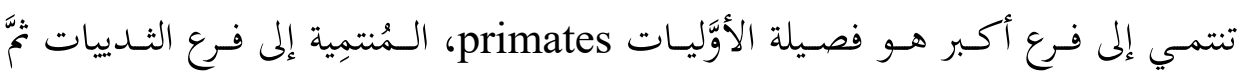
الفقاريات، وذلك ضمن تصنيف الكائنات الحية في علم البيولوجيا.

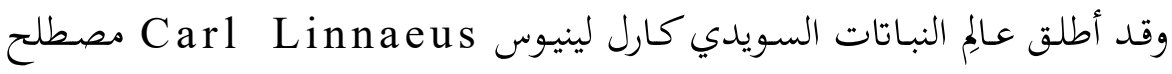
"هوموسابيان" Homo Sapiens، الذي يعني الإنسان العاقل، على البشر هذه الأيام،

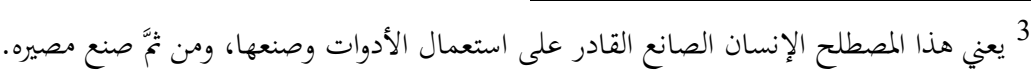

${ }^{4}$ Diener, Paul W. Religion and Morality: An Introduction, Westminster John Knox Press, 1997, p 72. 


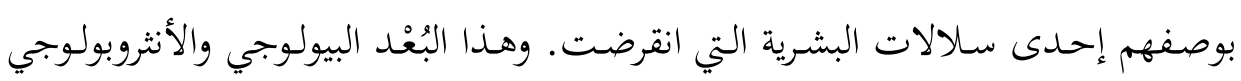

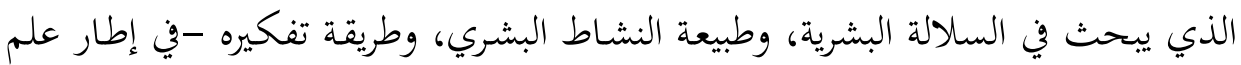

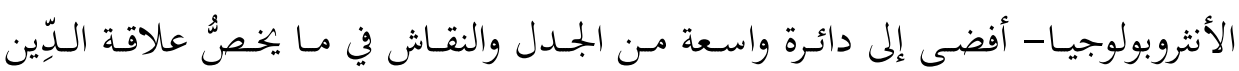

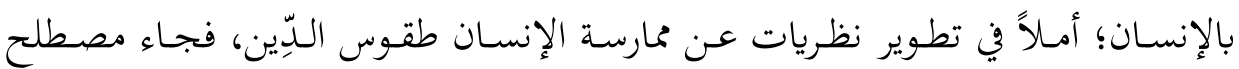

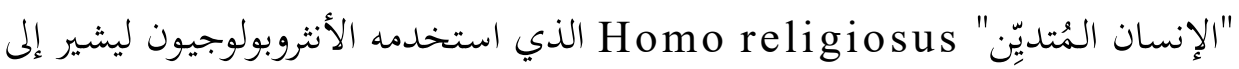

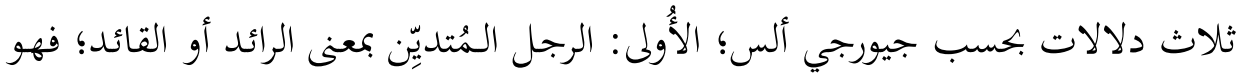

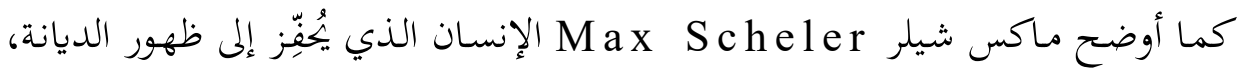

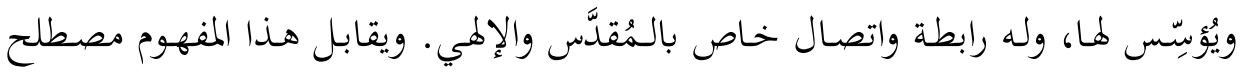

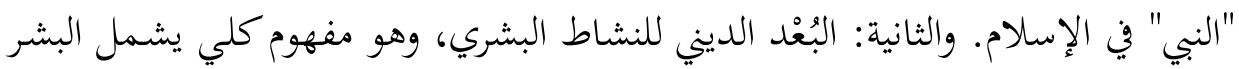

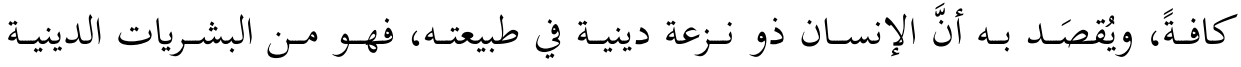
homines religiosi

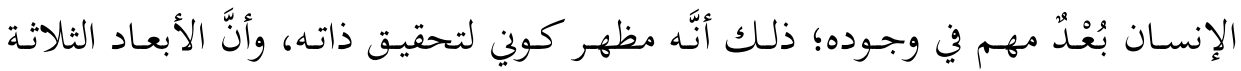

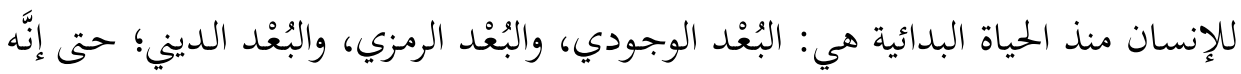

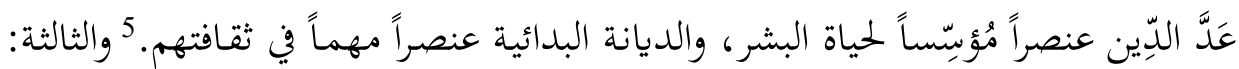

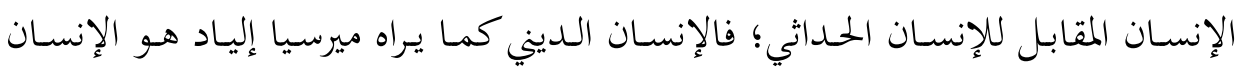

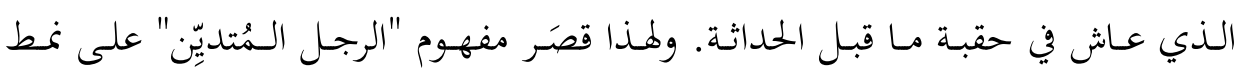

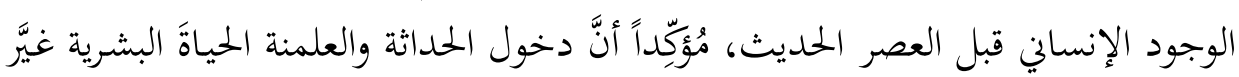

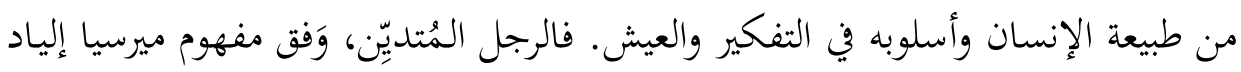

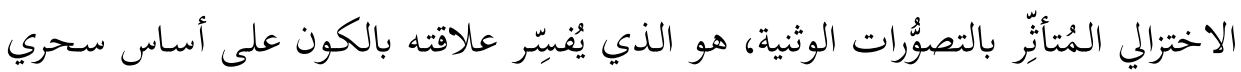

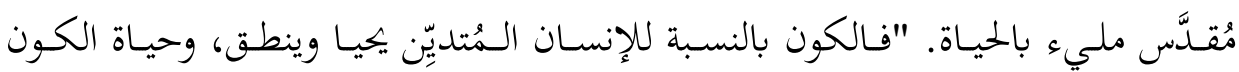

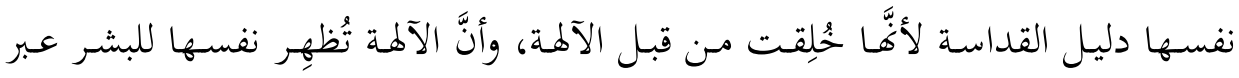

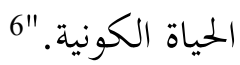

5 Alles ،Gregory D. "Homo religiosus".in: Jones, Lindsay, (editor in chief). Encyclopedia of Religion. 2nd ed. Detroit: Macmillan Reference USA, 2005, pp 4110-4111.

6 6 إلياد، ميرسيا. السُقْدَّس والـمُدَنَّ،، ترجمة: عبد الهادي عباس، دمشق: دار دمشق للطباعة والنشر، 1988م، 


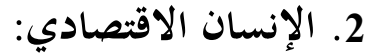

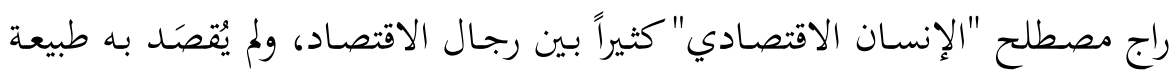

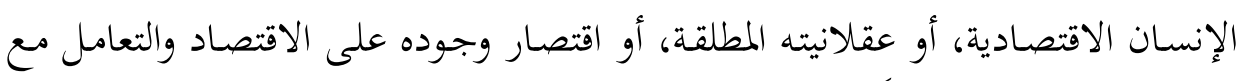

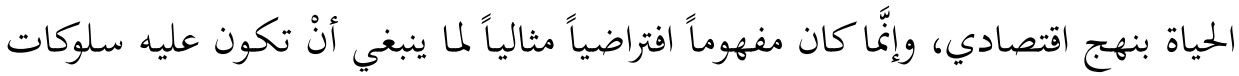

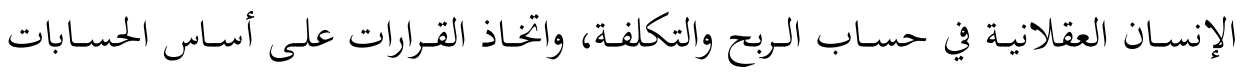

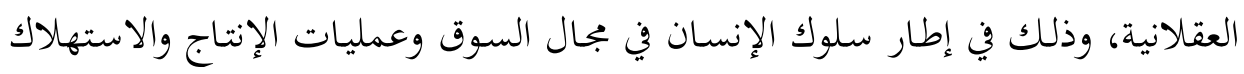

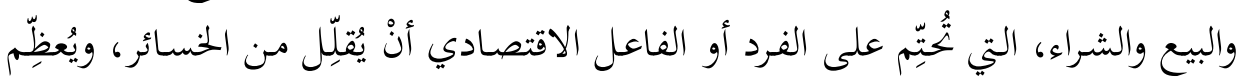

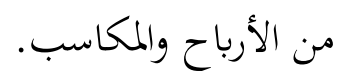

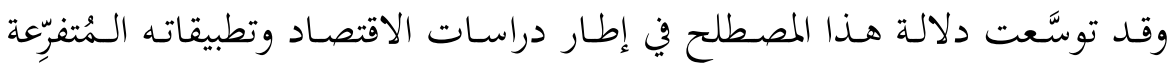
منـه، لتشـمل دراسـة السـلوكات العقلانيـة، في إطـار اقتراب الخيـار العقلاكي، وتطبيقاهـا

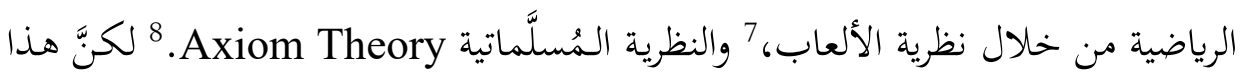

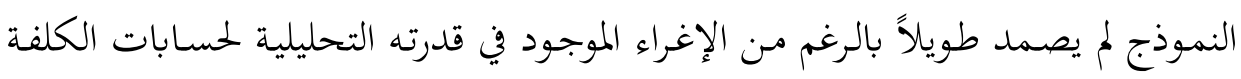

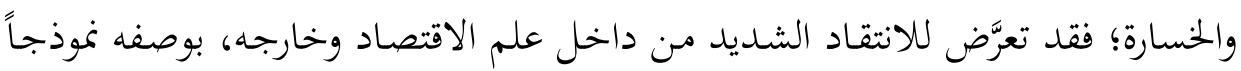

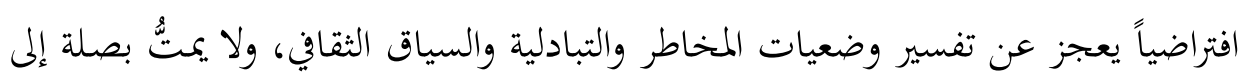

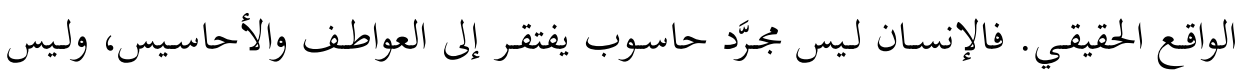
عقلانياً طوال الوقت.

\section{3. الإنسان السياسي والاجتماعي:}

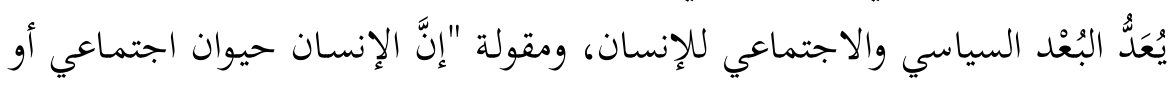
سياسي zoon politikon بطبعه" مـ الأبعاد والمقولات القديمة في تاريخ الفكر لإنس

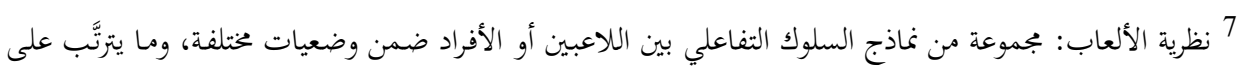

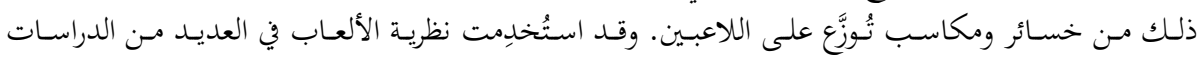

$$
\text { الاقتصادية والسياسية والاجتماعية. }
$$

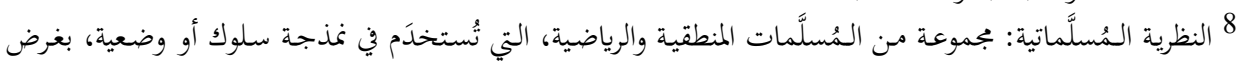

$$
\text { البرهان عليها، أو صياغة نظرية، أو نموذج نظري. }
$$

${ }^{9}$ Kirchgässner, Gebhard. Homo Economicus: The Economic Model of Behaviour and Its Applications in Economics and Other Social Sciences, Springer Science \& Business Media, 2008, p 25. 


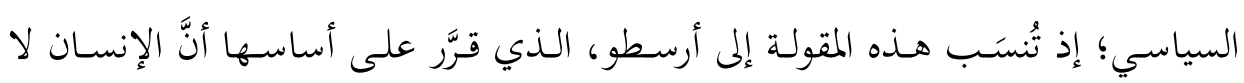

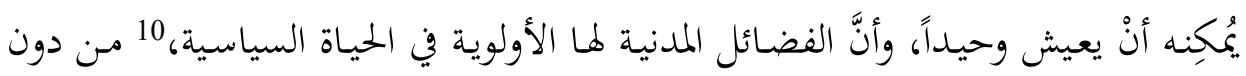

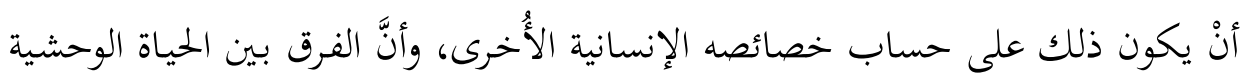

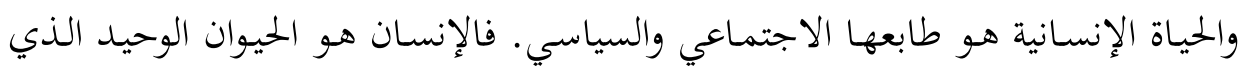

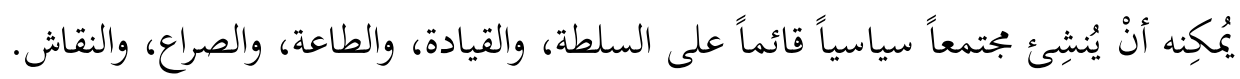

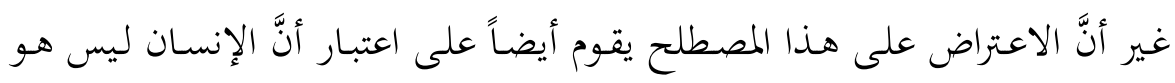

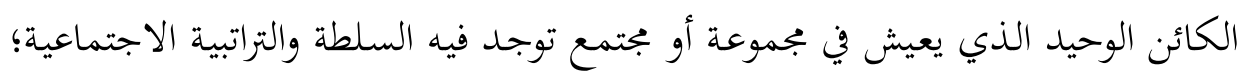

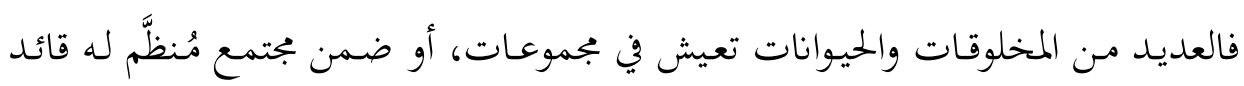

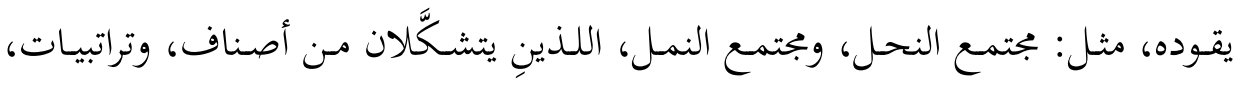

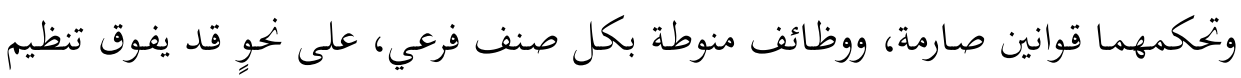

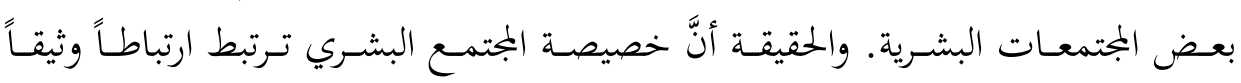

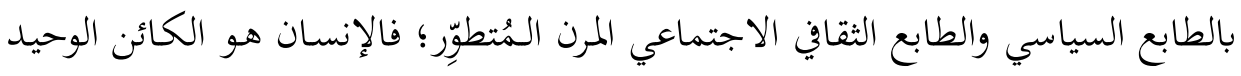

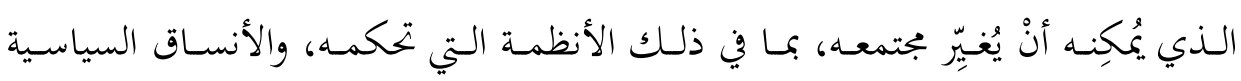

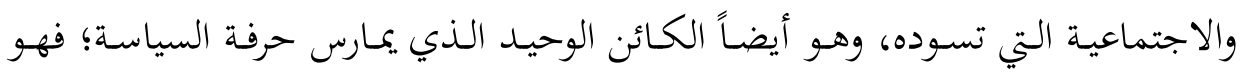
كائن سياسي بامتياز، والسياسة هي خصيصة إنسانية أيضاً.

\section{4. الإنسان الفيلسوف:}

تناولت الفلسفات الغربية موضوع الإنسان بإسهاب، وأفرزت أشهر مدارسها، مثل:

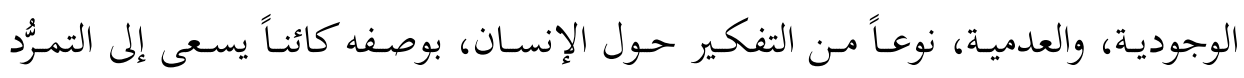

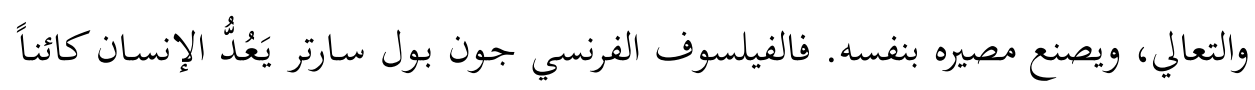

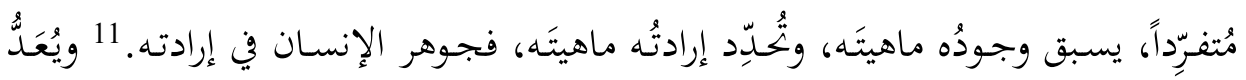

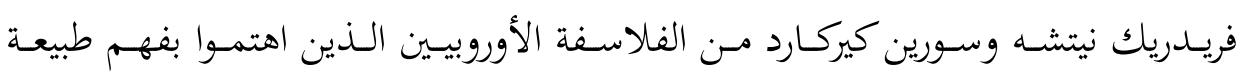

${ }^{10}$ Kraut, Richard and Skultety, Steven (editors) Aristotle's Politics: Critical Essays, Rowman \& Littlefield, 2005, p 38.

11 سارتر، جان بول. الوجودية مذهب إنساني، ترجمة: عبد المنعم الحفني، القاهرة: الدار المصرية للطباعة والنشر،

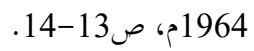


الإنسان وماهيته، بوصفه كائناً مُفكِكراً يُفِكِكر في ماهيته وجوهره، فيعمل هذا التفكير على تحويل شروط وجوده الأخلاقية؛12 شرط التحرُّر من القيود الفكرية والدينية والأخلاقية

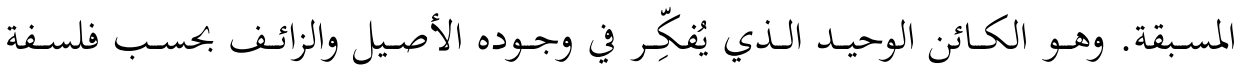

$$
\text { هيدجر الوجودية. }
$$

وتتفق كل هذه التصوُّرات على أنَّ الإنسان هو سيد مصيره، وأنَّهَ قادر -باستخدام

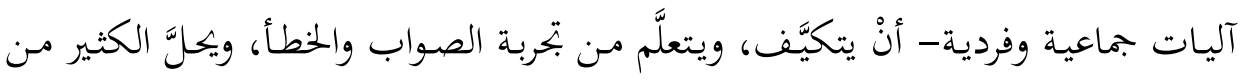

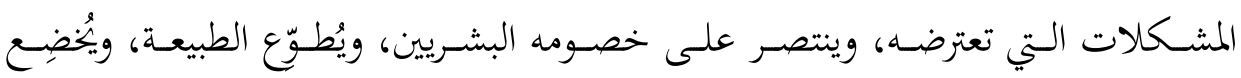

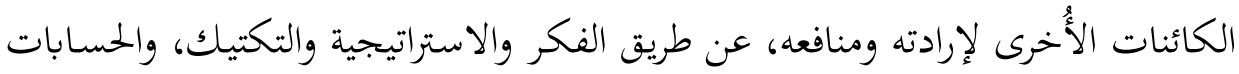
العقلانية، والتفكير الأخلاقي البراغماتي.

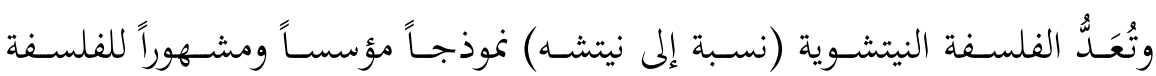

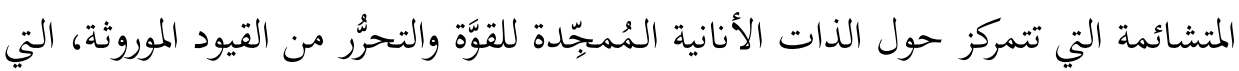
تُؤسِّس للقطيعة مع الدِّين، وتُمهِّه لفلسفة التفكيك، التي بدأها نيتشه بهدم فكرة الفضيلة

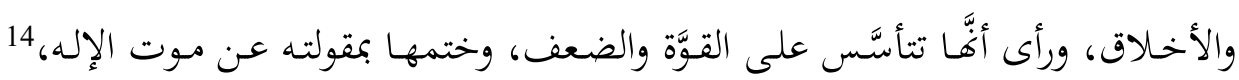

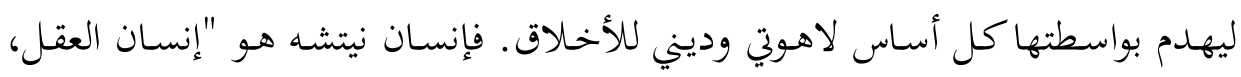

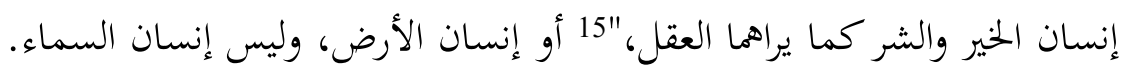

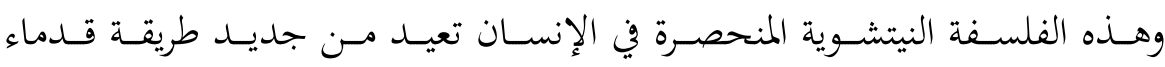

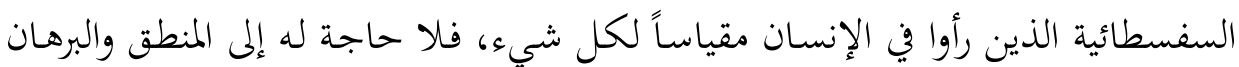

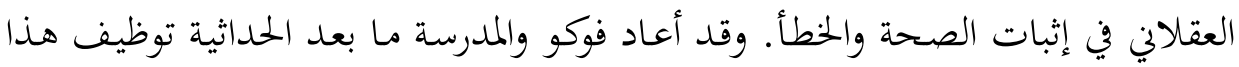

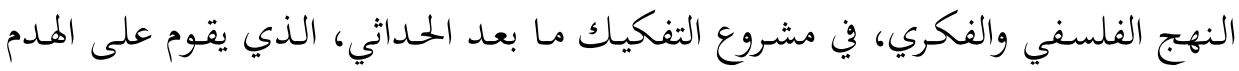

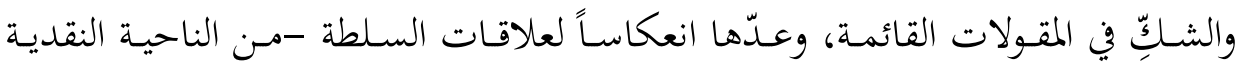

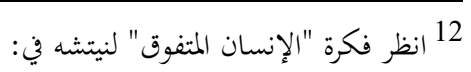

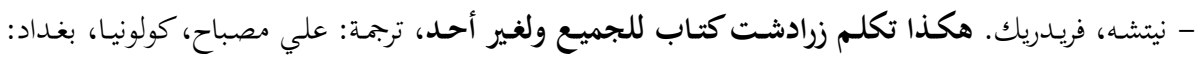

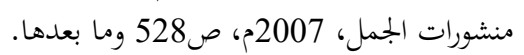

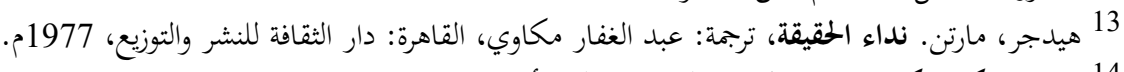

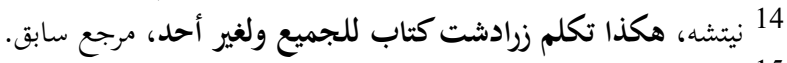

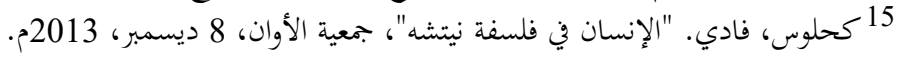


المعرفية، والناحية المنهجية- على القراءة المزدوجة للنص، والتأويل المُتعلِّدد، والاختلاف

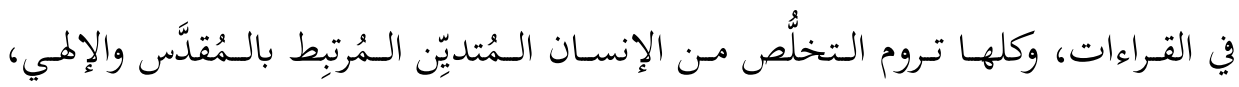

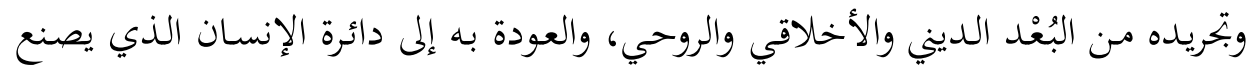

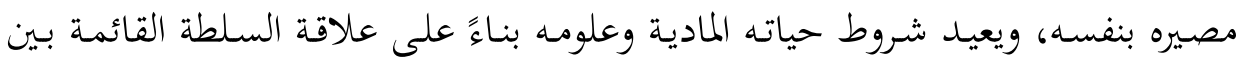
البشر.

\section{ثانياً: مفهوم "الإنسان" في التصوُّر الإسلامي المعاصر}

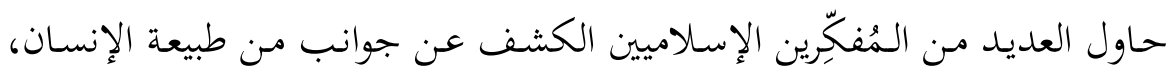
ودراسته من منظور النص القرآني، وحصيلة ثقافتهم الإسلامية وثقافتهم المعاصرة؛ بهدف التصدّي للهجمة الإلحادية المادية التي بدأت تنتشر في الأوساط الفكرية المُرتبطة بالفكر وحرِ الفلسفي الغربي والمذاهب والأيديولوجيات الماركسية والليبرالية والعلمانية المعادية للدّّين، التي يعدّوها دخيلة على الفكر الإسلامي وثقافة المجتمعات الإسلامية، فضلاً عن إبراز

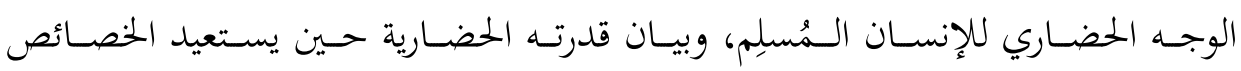
الحضارية والإنسانية كما طلبها منه القرآن الكريم.

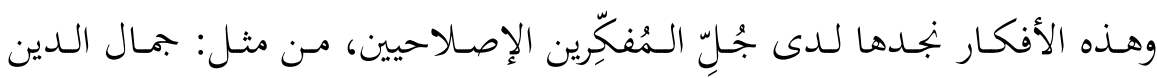

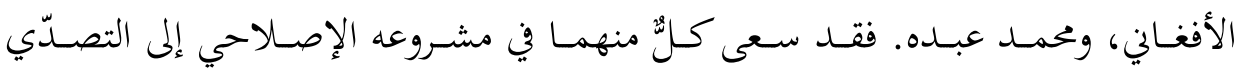
للأفكار الإلحادية الغربية الوافدة، وحاول إثبات رقي الفكر الإسلامي وحضاريته ومدنيته

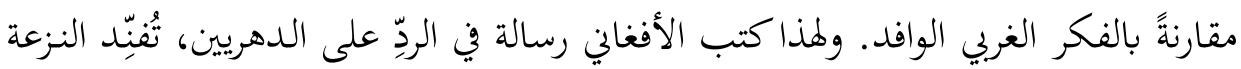

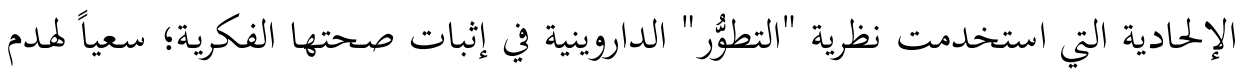

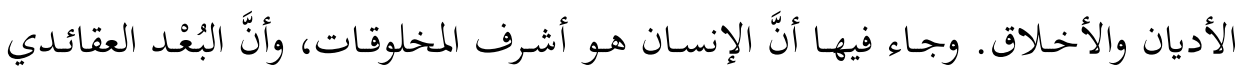

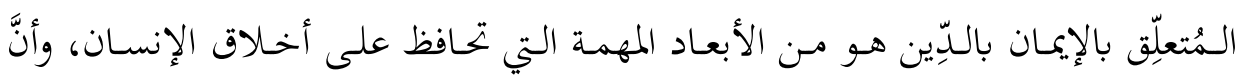

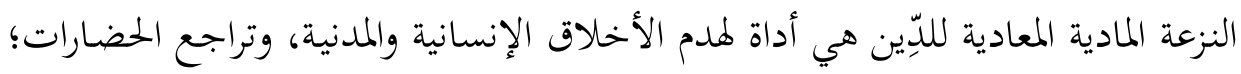

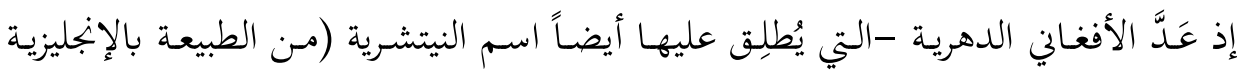


Nature - مـذهباً فكرياً هـدّاماً، فقـال: "لا جرم أنَّ هـذه الطوائف إذا استفحل أمرهـا، وقوي ساعدها على المجاهرة بأعماها، فقد تكون سبباً في انقراض النوع البشري."16

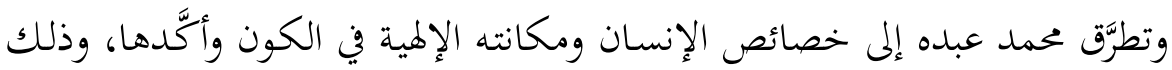

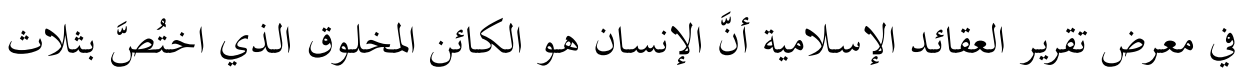

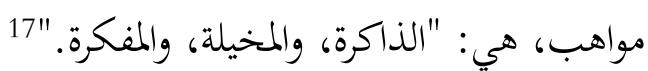
وفي منتصف القـرن العشرين، بـأت توجُّهات في الفكر الإسلامي تُرِّزّز على أهمية

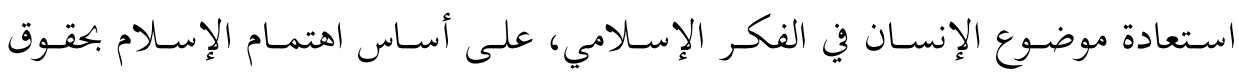

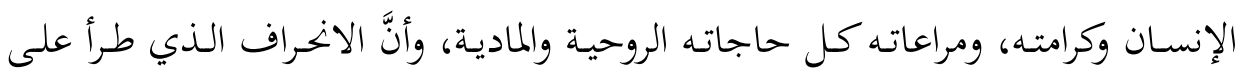

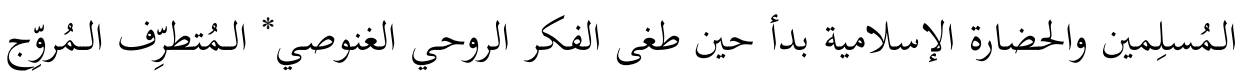

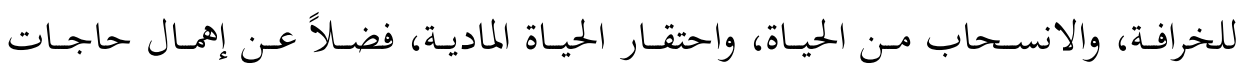

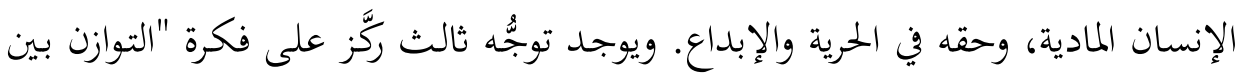

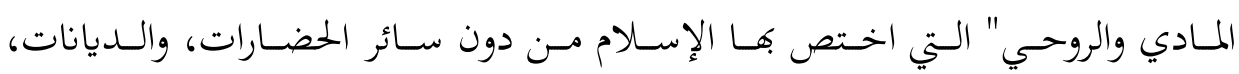
والفلسفات الدينية، والأيديولوجيات.

\section{1. توجُُهات في التفكير الحضاري:}

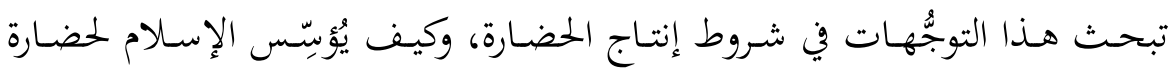
إنسانية شاملة، يتكامل فيها الوحي مع الواقع، والمادي مع الروحي. ومـن أبرز المُفكِِرين

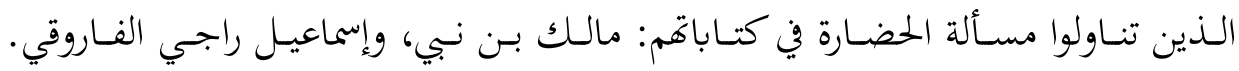

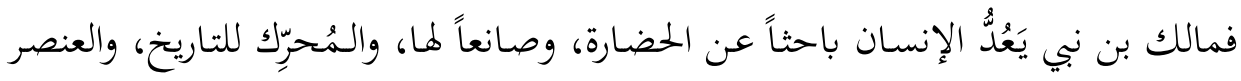

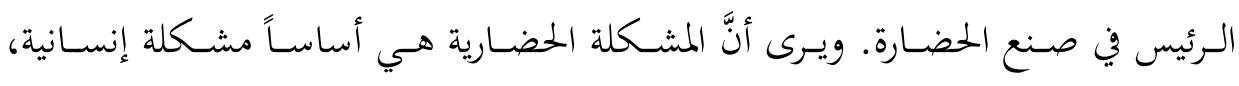

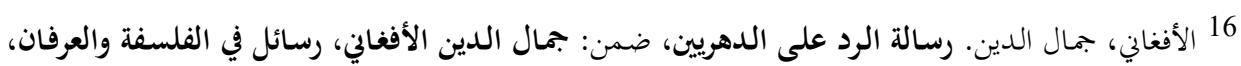

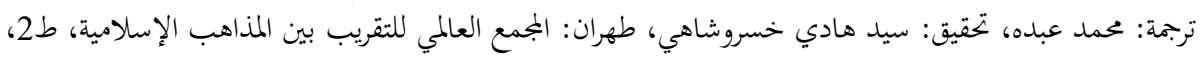

$$
\text { 1421هـ، ص181 }
$$

- عبده، محمد. رسالة التوحيد، تحقيق: محمد عمارة، القاهرة: دار الشروق، 1894مان 1994م، ص73 وما بعدها.

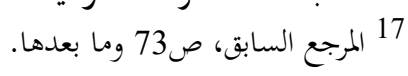

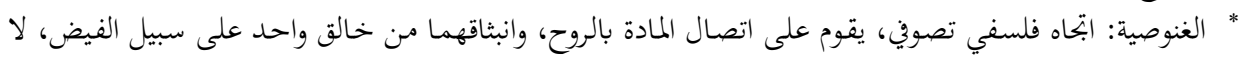
على سبيل الخلق. 
يجكمها وعي الإنسان وأخلاقه وثقافته؛ فالحضارات تعلو وتزدهر برقي الإنسان ووعيه

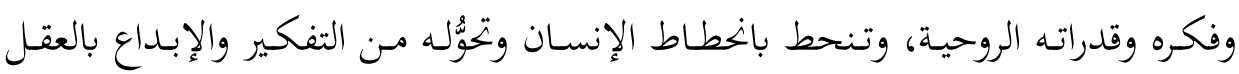

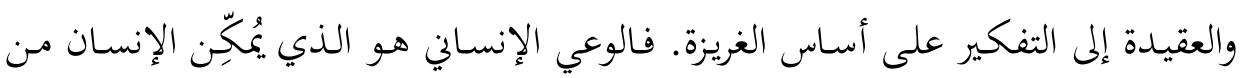

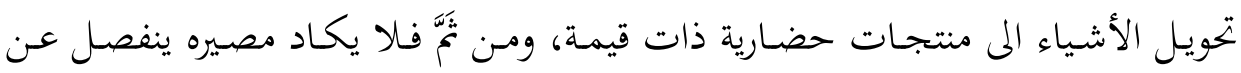

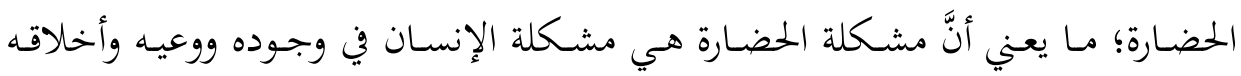

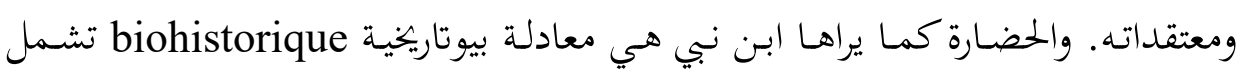

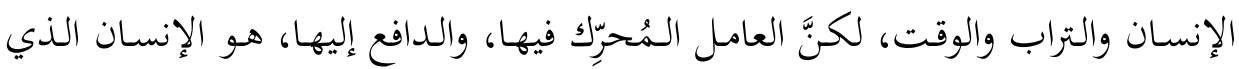

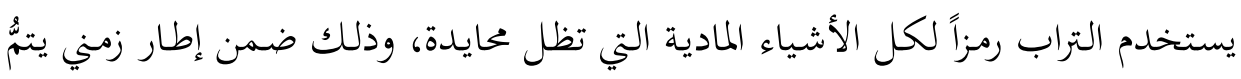
فيه صنع الأشياء وصياغة الحضارة. 18

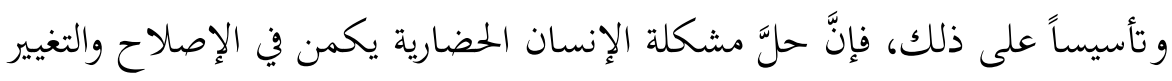

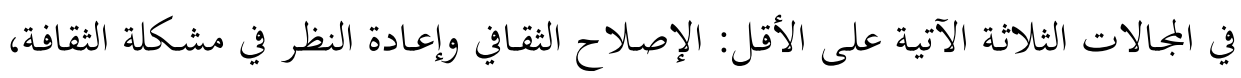
وإعادة النظر في قضية العمل وقيم العمل والإتقان واحترام الوقت، وإعادة النظر في قضية الإحلية الرأسمال البشري والمادي.

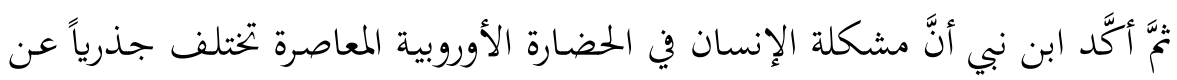

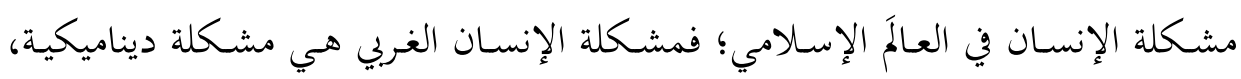

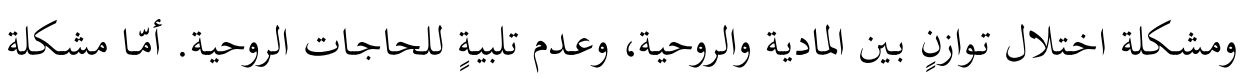

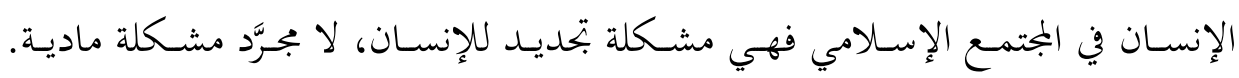

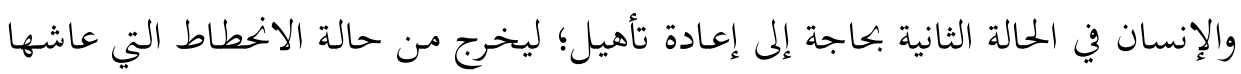

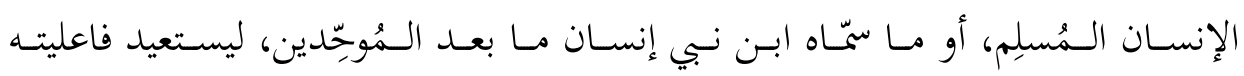
الحضارية.20

وفي المقابل، نظر الفـاروقي إلى اللدّين بوصفه مُكوِّناً لا يفـارق الحضـارات، بـل هـو

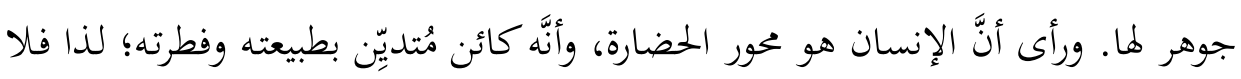

18 Bennabi, Malek, Les conditions de la renaissance: problème d'une civilisation, Alger: Éditions ANEP, 2005, p 49.

${ }^{19}$ Ibid., p 60.

${ }^{20}$ Ibid., pp 81-82. 
عجب أنْ تقوم كل الحضـارات على الدِّين، ويكون لها جوهر ديني. فكل حضارة لها

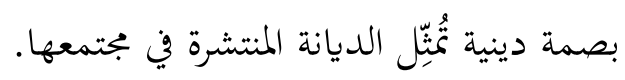
وقد أكَّد الفاروقي أنَّ مبدأ التوحيد هو الجوهر الذي قامت عليه الحضارة الإسلامية؛

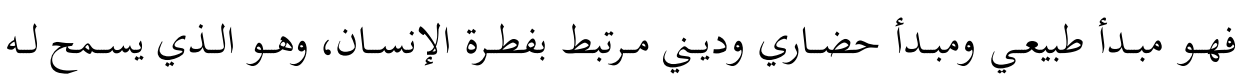

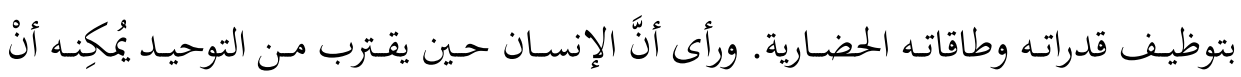
يصنع الحضارة التي تنتج العلوم والمعارف الدينية والكونية على أُسس علمية بتريبية عقلية؛ إذ قال: "لم تنتج المسيحية علوماً طبيعية مدى ألف سنة تحكَّمت في عقول النـاس. ولم ينتج المسيحيون العلوم إلا بعد أنْ تحرَّروا مـن عدم التوحيد الذي فرضته عليهم المسيحية، وبعد أنِ انتقلت إليهم علوم المُسِمِين، وحكمت الهندوكية والبوذية آسيا وجنوب شرقها مدى ألف سنة لم يتقدَّم أهلها إلى مستوى التفكير العلمي، ولكنْ ما أنْ أسلموا ووسَّدوا

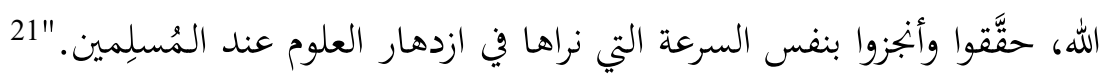

\section{2. توجُهات في التفكير الأيديولوجي:}

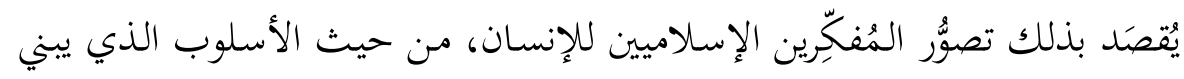

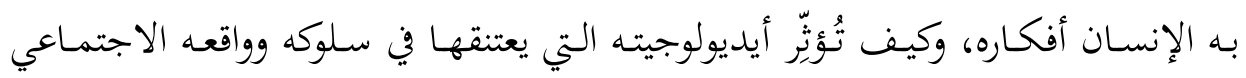
والسياسـي الـذي يسـى إلى تغيـيره عـن طريـق الـدعوة، والإصـلاح الفكـري، والنضـال

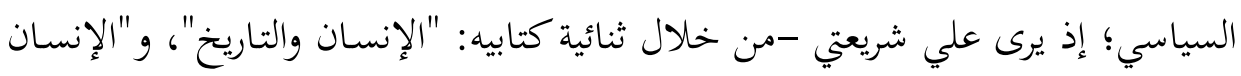

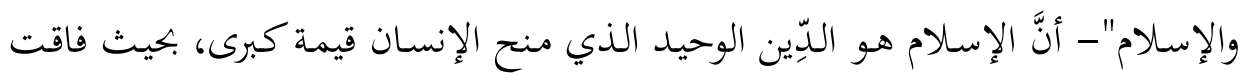

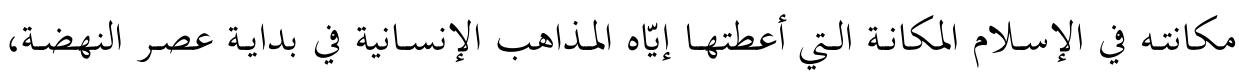

$$
\text { ضمن ما يُسمّى نظرية أصالة الإنسان. } 22
$$

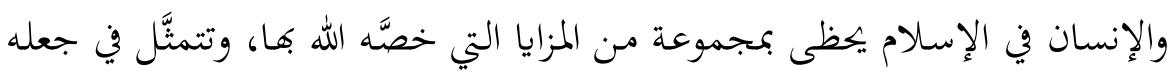
خليفة له على الأرض، وحمل أمانته فيها، وتفضيله على الملائكة بالعلم. وقد عللَّل شريعتي

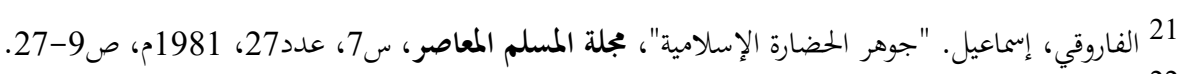

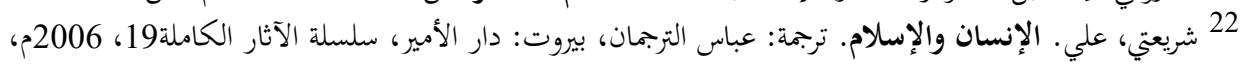


ذلك بقوله: "قيمة الكائن وأصالته هما بمقدار علمه ومعرفته، وليس بعنصره. "23 يضاف إلى ذلك أنَّ الإنسان هو كائن مسؤول عن مصيره الذي يصنعه بيديه، وهذه الفكرة تبدو واضحة جلية في القرآن الكريم.

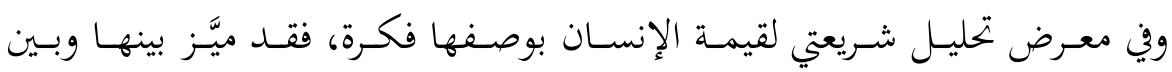

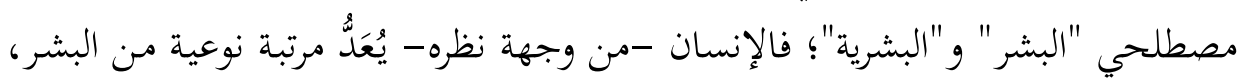

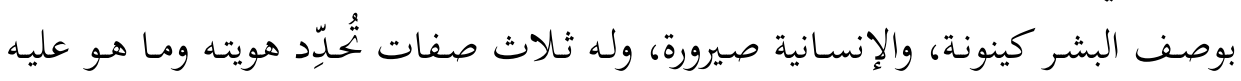

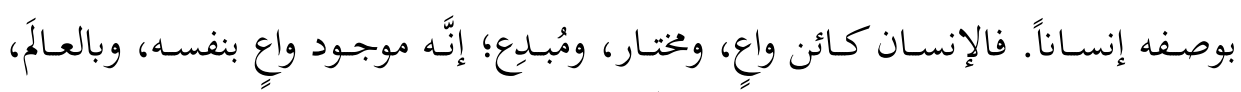

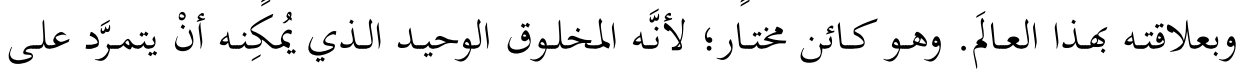

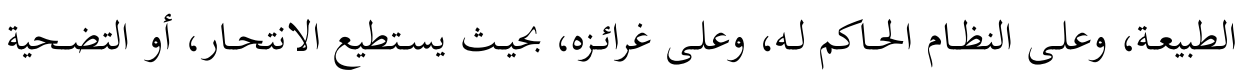

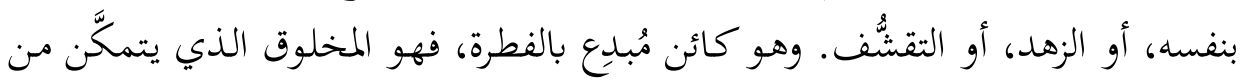

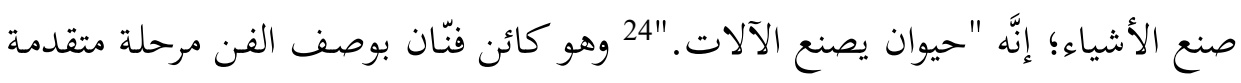

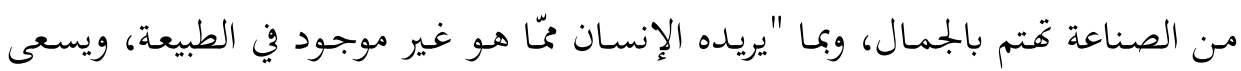

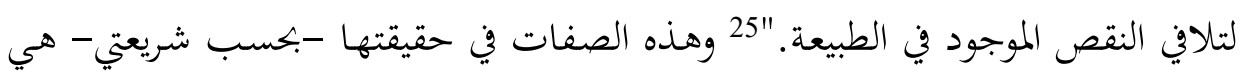

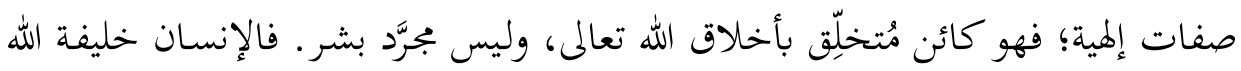

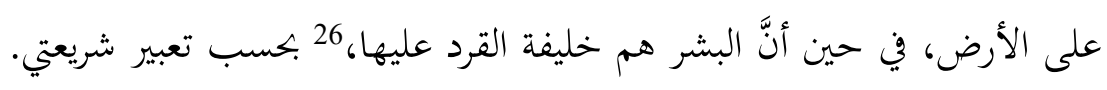

\section{3. توجُّهات في التفكير القرآي الكلامي والعقائدي:}

يُقصَد بذلك الأبحاث التي تدور حول موضوع الإنسان في مجال علم الكلام والعقائد

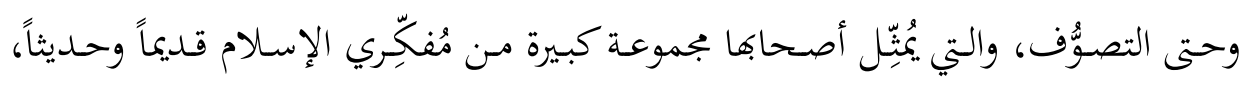

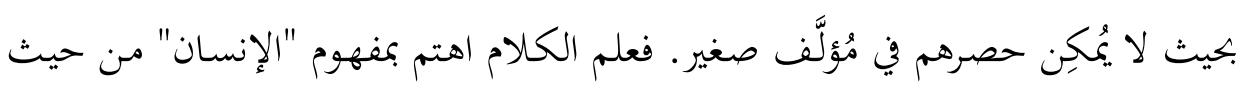

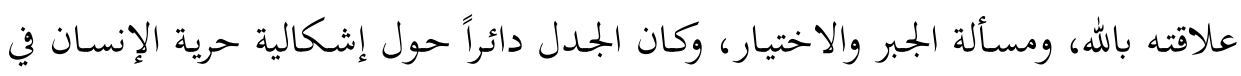
اختياره، وهو ما عكسته مدارس علم الكلام، بين المعتزلة والجهمية والأشاعرة والماتريدية.

$$
23 \text { 25 } 23 \text { المرجع المرابق، صالمرجع السابق، ص157. }
$$


وقد ارتبطت هذه الإشكالية -التي ظلّت عصية على الحلِّ-- بذرائع سياسية تتعلَّق

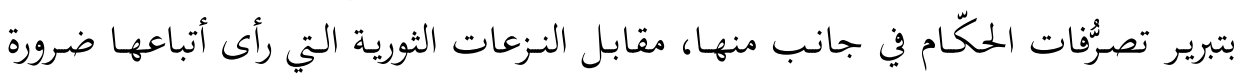

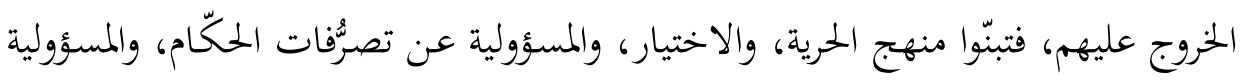

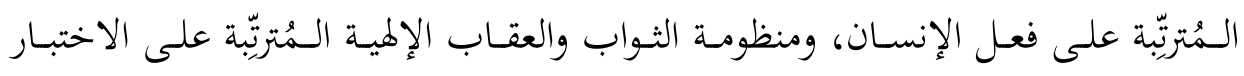

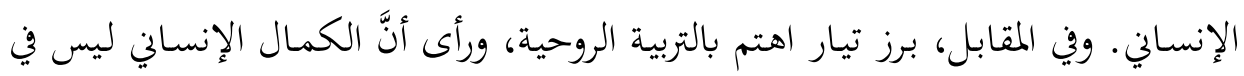

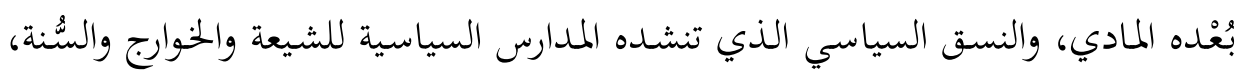

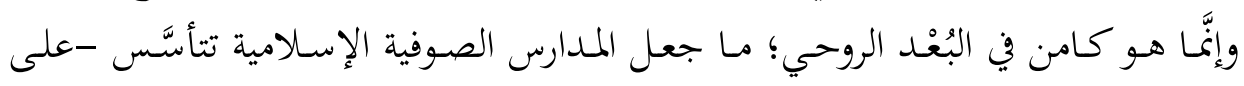

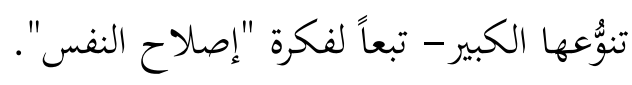

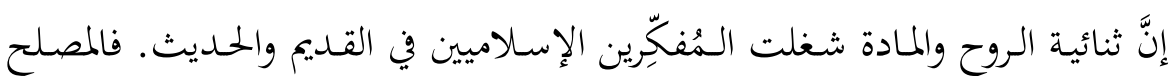

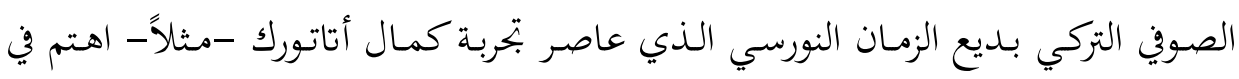

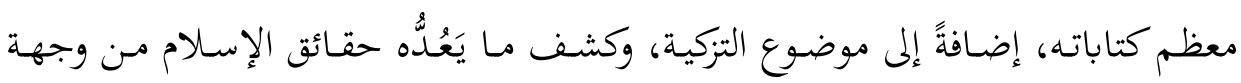

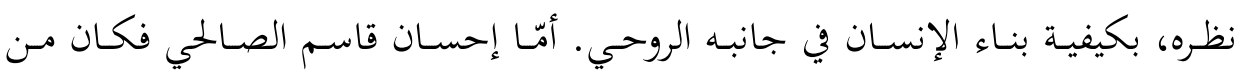

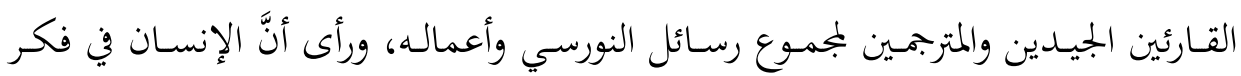
النورسي هو محور التزكية التي تمدف إلى إعادة صياغة إنسان مُسلِم جديد، وأنَّه قد يكون

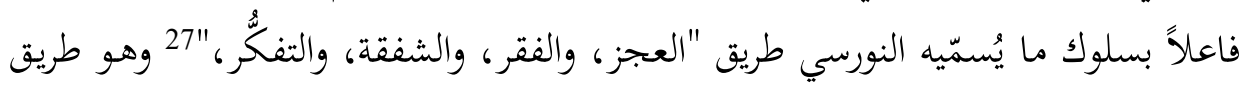
يكشف عن جوهر الإنسان وحقيقته الروحية والأخلاقية الفطرية السليمة، التي تعيد إليه توهُّجه الروحي واستقامته الأخلاقية. وأمّا علي عزت بيجوفيتش فرأى أنَّ الإنسان كائن له حاجات مادية وأُخرى روحية،

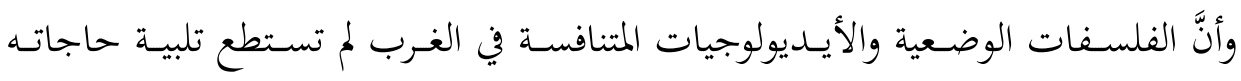

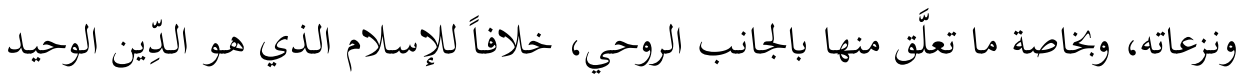

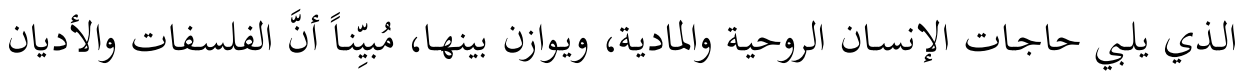
العالمية تمحورت حول ثلاث رؤى لتقصّي حاجات الإنسان، هي: الرؤية المادية، والرؤية

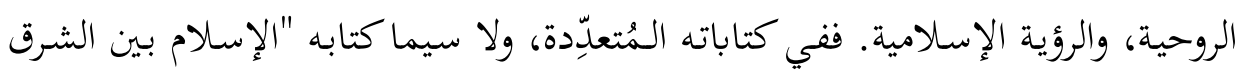
27 الصالحي، إحسان قاسم. "دور رسائل النور في صياغة الإنسان"، موقع نافذة النور، تاريخ الاسترجاع: 10 يونيو 


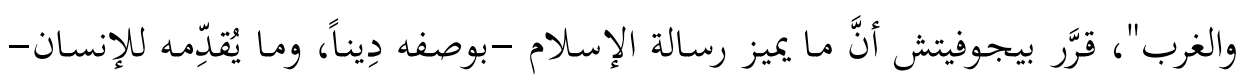

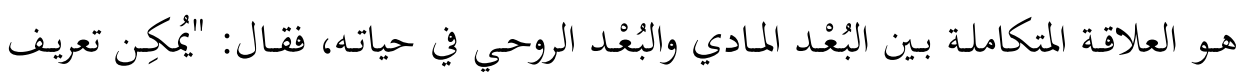

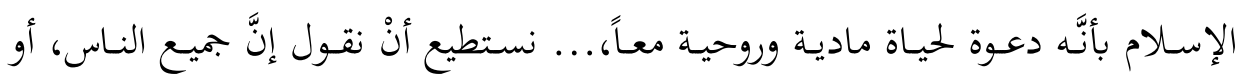

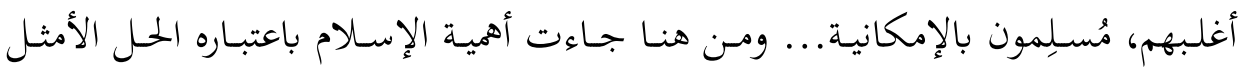

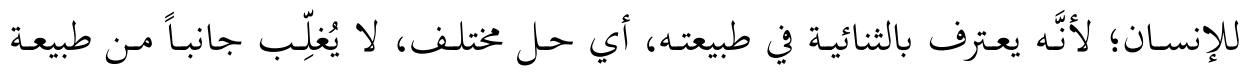

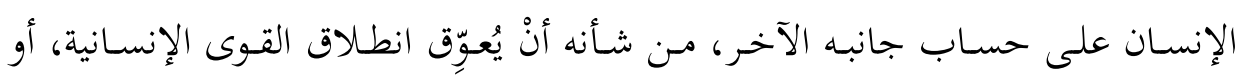

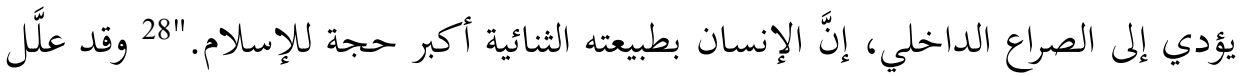

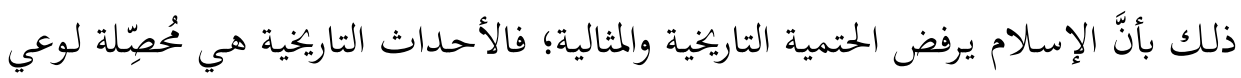

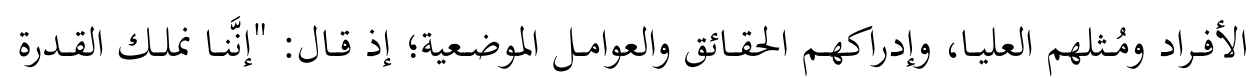

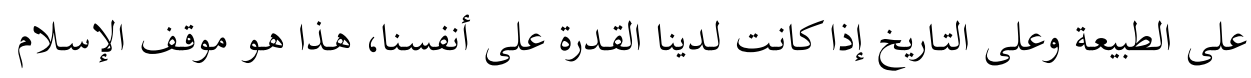

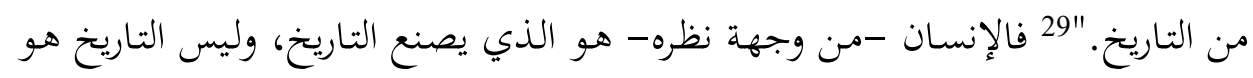

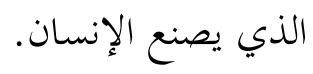

\section{ثالثاً: خصائص الإنسان بناءً على الحطاب القرآين}

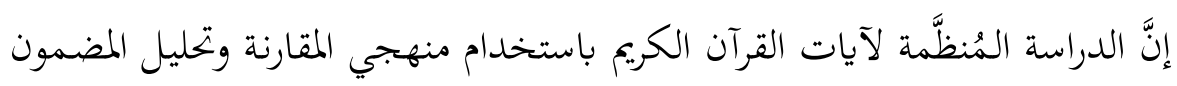

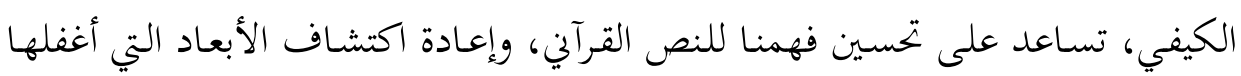

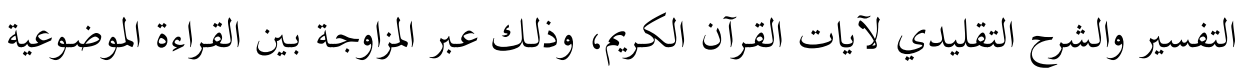

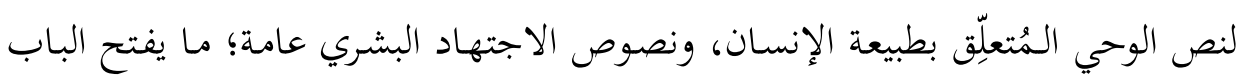

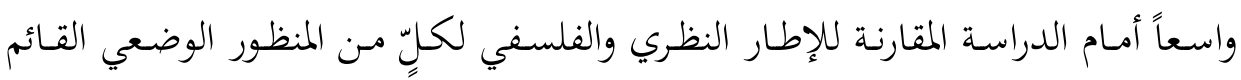

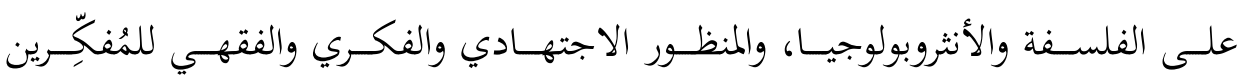

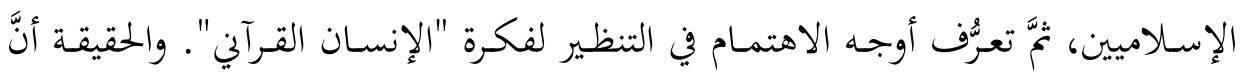

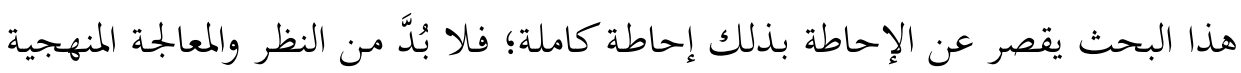
28 بيجوفيتش، علي عزت. الإسلام بين الشرق والغرب، ترجمة: عممد يوسف عدس، القاهرة: دار النشر للجامعات،

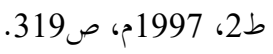

$$
\begin{aligned}
& 29 \text { المرجع السابق، ص325. }
\end{aligned}
$$


لآيات القـرآن الكريم وَفـق منهجيـة تحليـل الخطــاب الوضعية، ومنهجيـة التـدبُّر والتثـوير الإيمانية.

ومفهوم "الإنسان" في القرآن الكريم يختلف عن مفهوم "الإنسان التوراتي"، أو إنسان

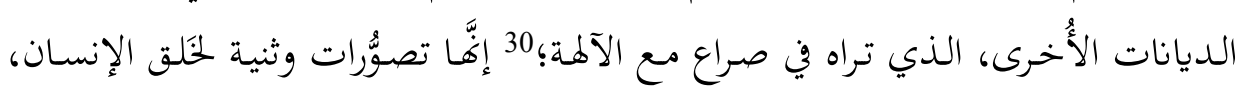
وتصوُرات إحيائية بدائية، تسرَّبت في الثقافة التوراتية والمسيحية، لتجعل الإنسان شبيهاً

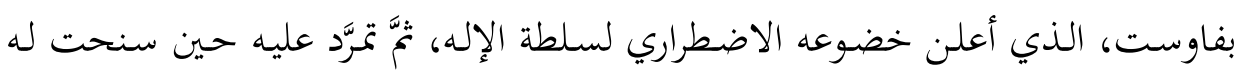
الفرصة. أمّا الإنسان في القرآن الكريم فمرتبط بوظيفةٍ وغاية في وجوده على الأرض.

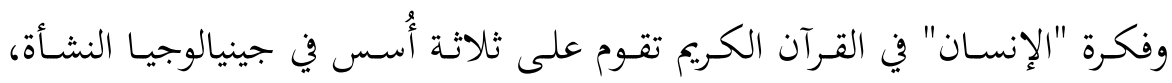
هي: الاستخلاف، والاصطفاء، والتكريم. ولمعرفة هذه الأُسس، لا بُدَّ من دراسة منهجية

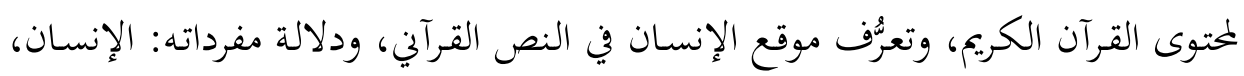

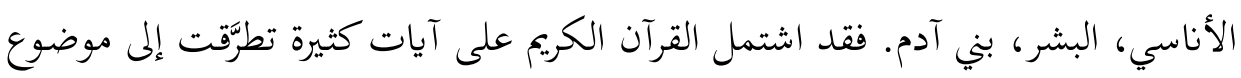

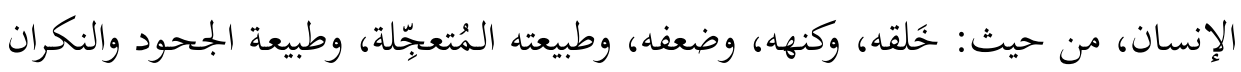

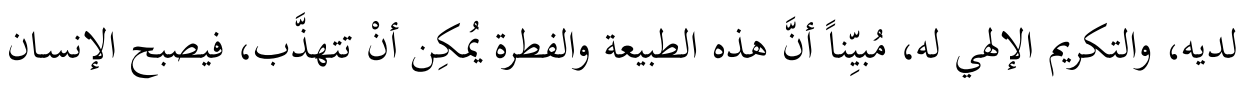
فوق الكائنات الأخرى، أو تفسد، فينحدر إلى مستويات دنيا أخلاقياً وسلوكياً.

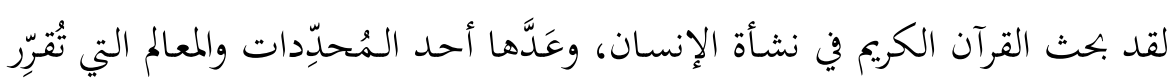

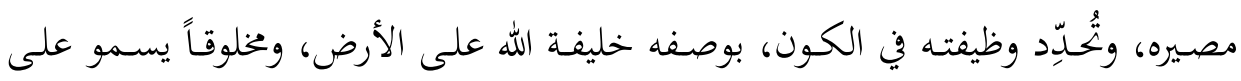
بقية المخلوقات التي سُخِرت لخدمته، والتي يشترك معها في الضرورات البيولوجية، والإطار البيولوجي، والسمات البيولوجية الأُخرى، من دون أنْ يكون -بالضرورة- امتداداً أخلاقياً ووجدانياً لما.

والجـدول الآتي يُمبّل إحصـاءً للآيات القرآنيـة التي أشـارت إلى الإنسـان مباشـة، أو

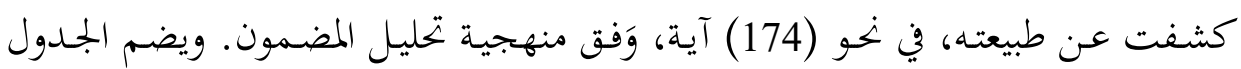

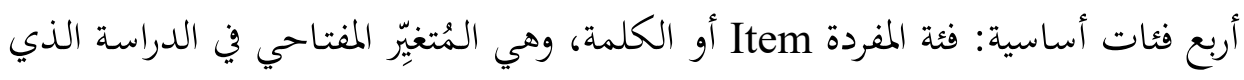

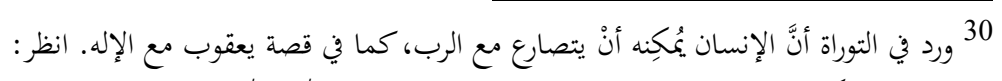

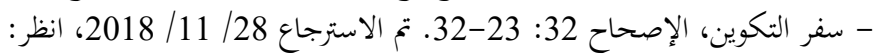

- https://st-takla.org/Bibles/Download-Arabic-Bible-pdf.html. 
يشـير إلى كيفيـة ورودهـا في الآيات، وفئهة التكـرار، وفئهة التصـنيف؛ أي الموضـوع الـذي

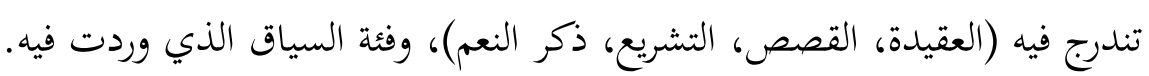

\begin{tabular}{|c|c|c|c|c|}
\hline السياق & التصنيف & التكرار* & المفردة & 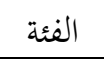 \\
\hline - على - الحلق الإنسان من طين: (12) مرَّة & 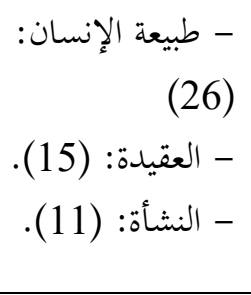 & (56) & الإنسان & الأُولى \\
\hline 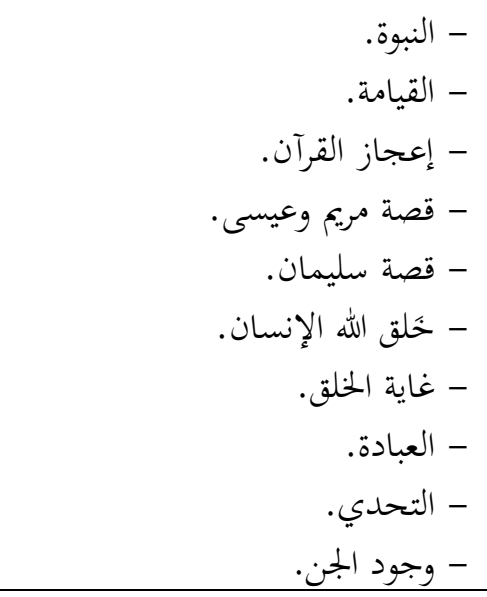 & - القصصيدة. & (15) & الإنس & 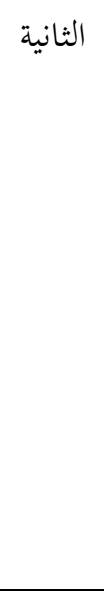 \\
\hline 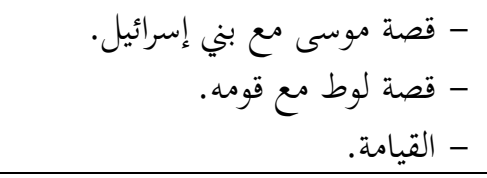 & - القصصيدة. & (5) & أناس & 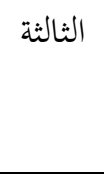 \\
\hline - نعمة الله على الإنسان. & - نعم الله. & (1) & أناسي & الرابعة \\
\hline 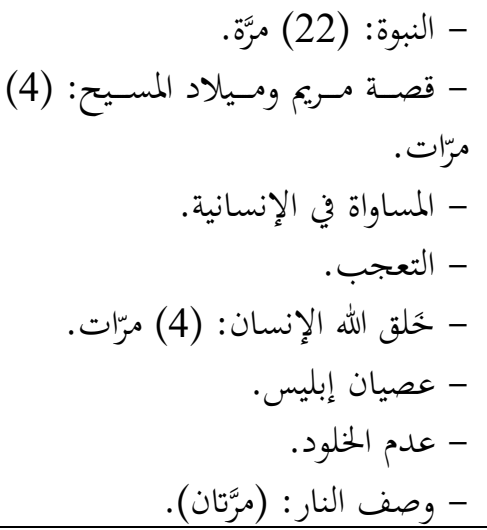 & - القصيدة. & (37) & بشر & الخامسة \\
\hline
\end{tabular}




\begin{tabular}{|c|c|c|c|c|}
\hline 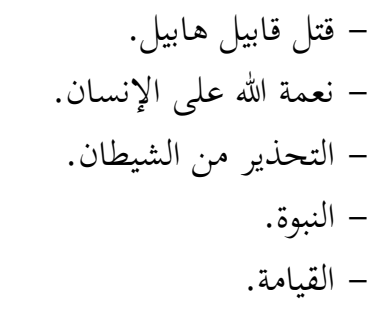 & - - التعم الله. & (8) & 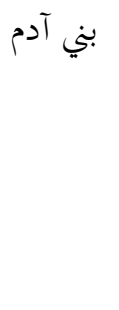 & السادسة \\
\hline - - خَلق الله. & - العقيدة. & (2) & 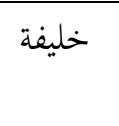 & 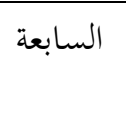 \\
\hline 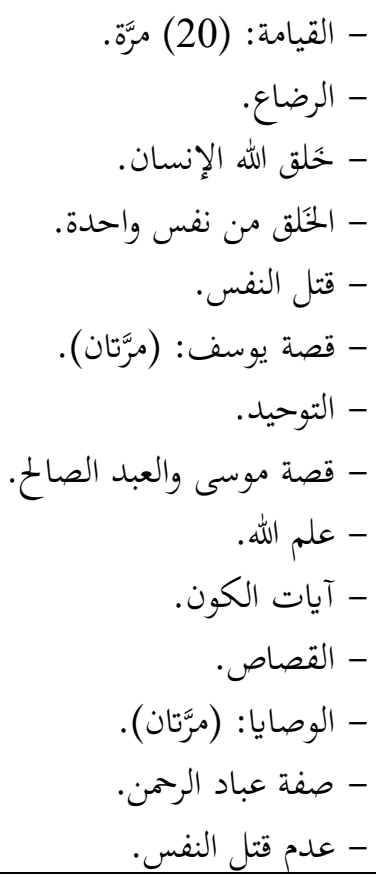 & - - التصصيدة. - التوجيه. & $(51)$ & نفس & الثامنة \\
\hline & & (174) & الجموع: & \\
\hline \multicolumn{5}{|c|}{ * تكرار عدد الآيات التي وردت فيها المفردة. } \\
\hline
\end{tabular}

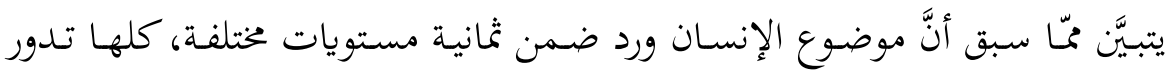
حول معالجة القضايا الأساسية الآتية: 
1. مفـردة "الإنسـان": ورد ذكر هـذه المفــدة في (56) موضعاً مـن القـرآن الكـريم،

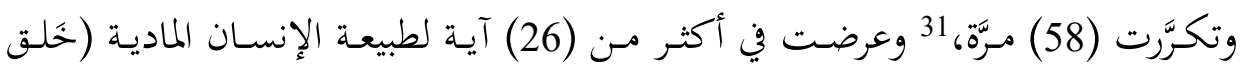

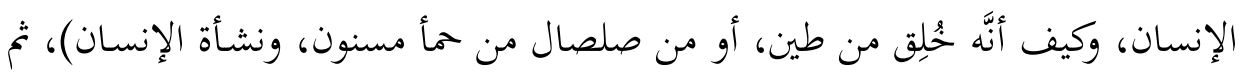

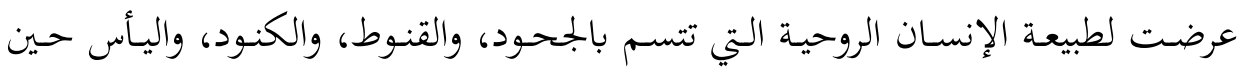

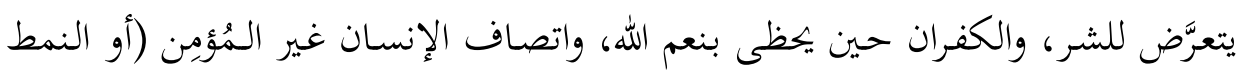

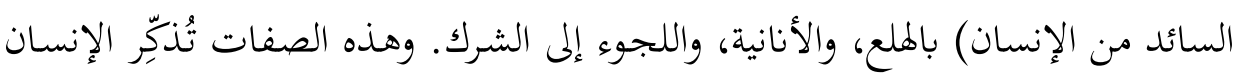

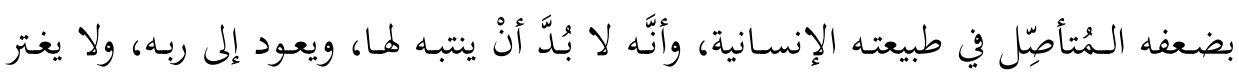
بنفسه.

2. مفردة "الإنس": ورد ذكر هذه المفردة في القرآن الكريم، في معرض الإشـارة إلى

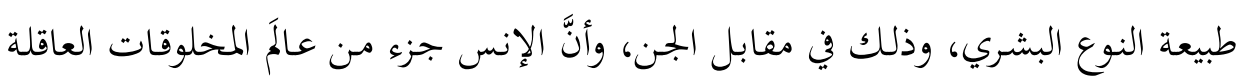

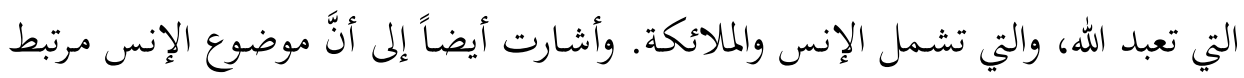

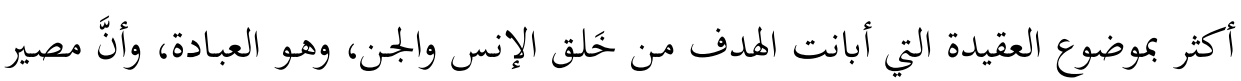

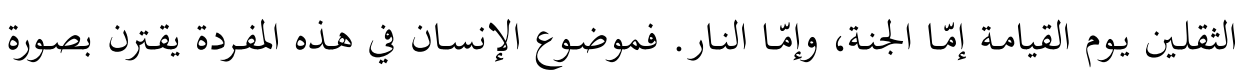
أكبر بأبعاد العقيدة الإسلامية التي تتعلَّق باليوم الآخر.

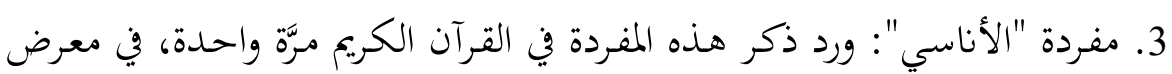

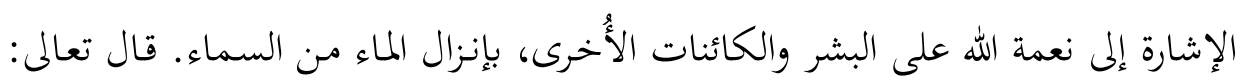

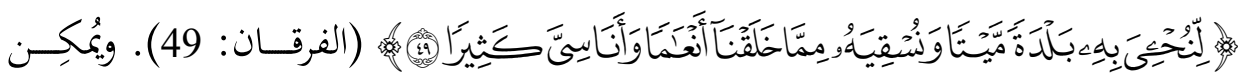
الإفادة من هذه الآية في الدلالة على تاريخ السلالات البشرية، ووجود جنس إنسي غير الجنس البشري الآدمي عمَّر الأرض (انظر: 1. الإنسان الأنثروبولوجي والبيولوجي).

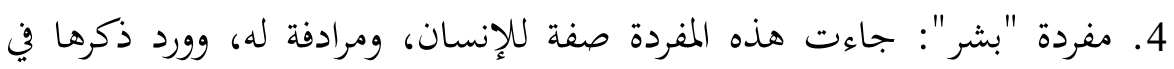
القرآن الكريم نخو (37) مرَّة، واقترنت كثيراً بموضوع النبوة والرسالة الإلهية والوحي، في معرده

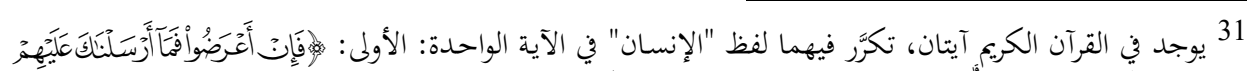

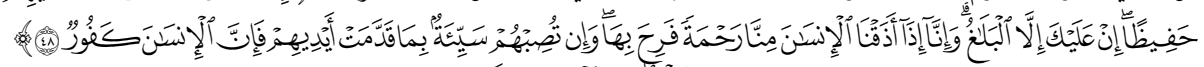

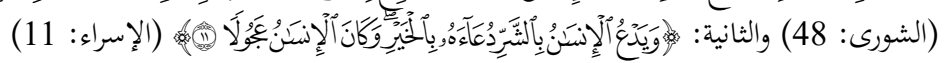


معرض الحديث عن الجماعات والأقوام الذين بُعِث فيهم الرسل والأنبياء، والذين تساءلوا

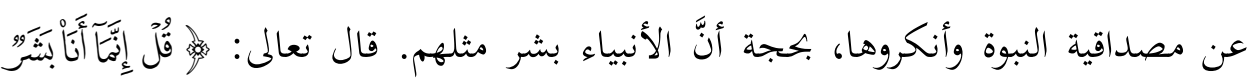

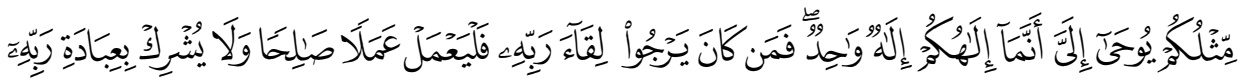

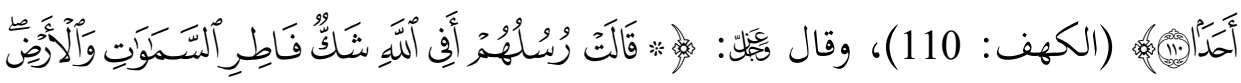

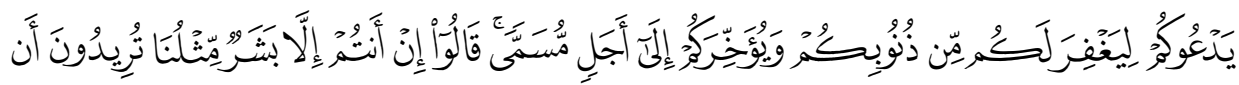

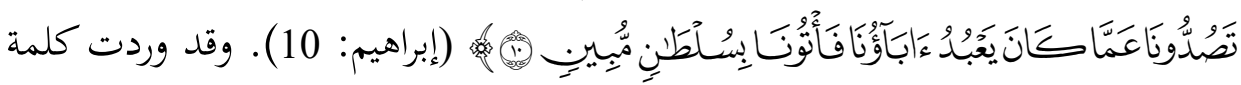
"بشر" في القرآن الكريم مرَّة واحدة، في معرض الإشارة إلى استحالة خلود الإنسان على

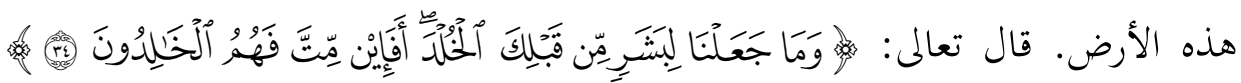

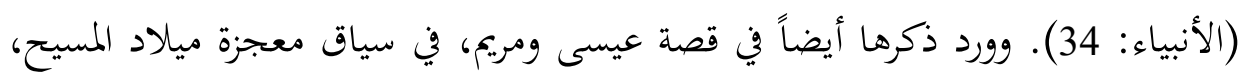

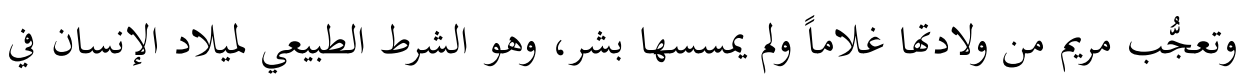

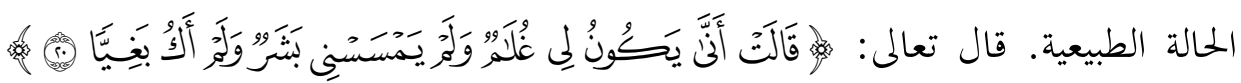
(مريم:20)

5. مفردة "بني آدم": وردت هذه المفردة ضمن فئة التوجيه، وذكر النعم، والتحذير من مكيدة إبليس. وجاءت مقرونة بالنداء في (5) مواضع من الذكر الحكيم، ووردت (4) نداءات منها في موضع واحد من سورة الأعراف (الآيات:26-31). ومن مجموع الآيات الثماني التي ورد فيها التوجيه إلى بني آدم، تصدَّر موضوع التذكير بنعمة الله على الإنسان،

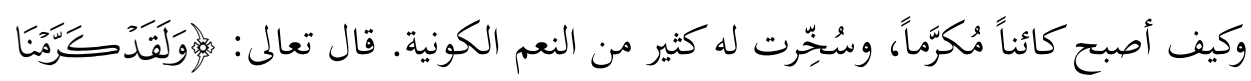

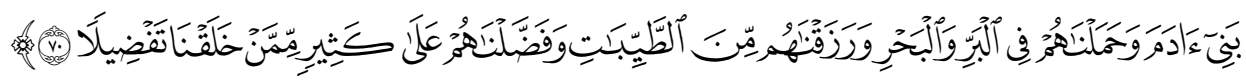
(الإسراء: 70). وقد ورد ذكرها أيضاً في سياق التحذير من الشيطان، في قصة آدرد وإخراجه من الجنة، ويف سياق بعث الأنبياء، ووجوب تصديقهم؛ بتوجيه توصية إليهم.

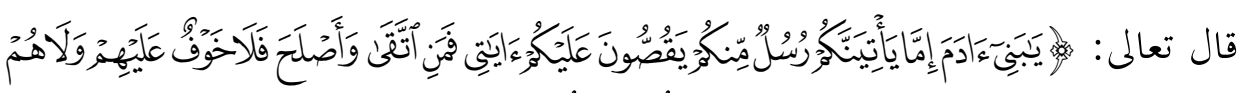

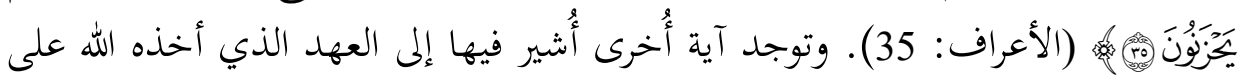

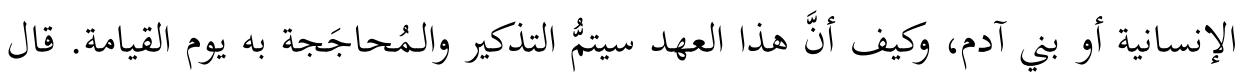




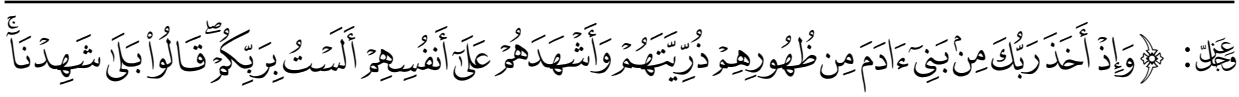

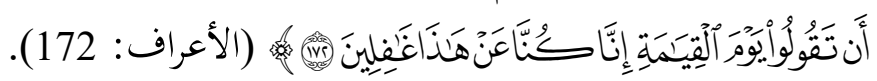
6. مفردة "خليفة": ورد ذكر هذه المفردة مرَّتين في القرآن الكريم، ولكنَّ المعنى الذيني

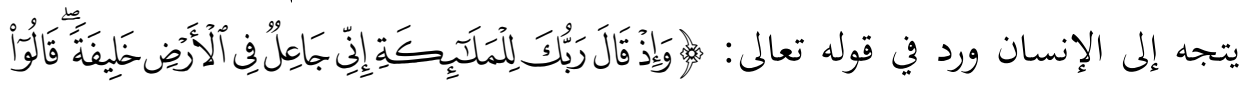

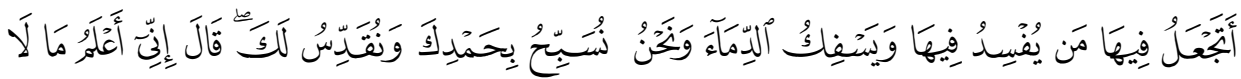

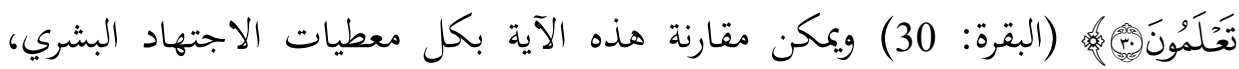

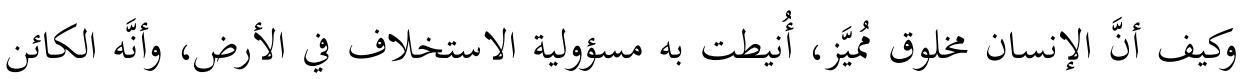

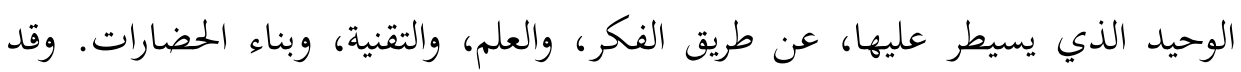

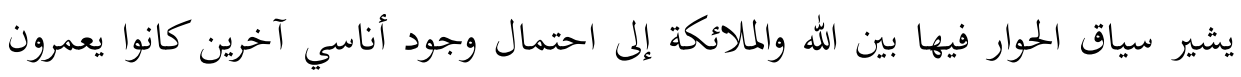
الأرض، لكنَّهم انقرضوا. 7. مفردة "النفس": جاءت هذه المفردة في المرتبة الثانية من حيث تكرار الآيات التي

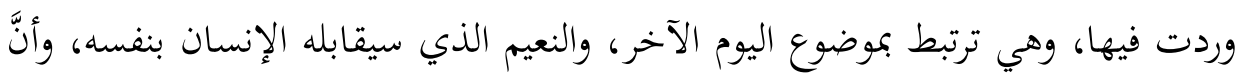

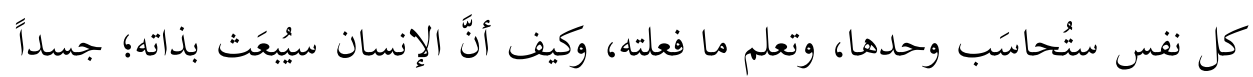

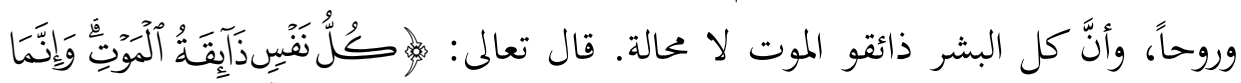

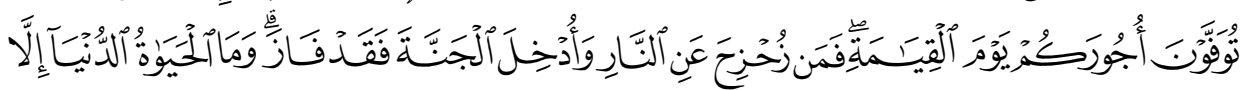

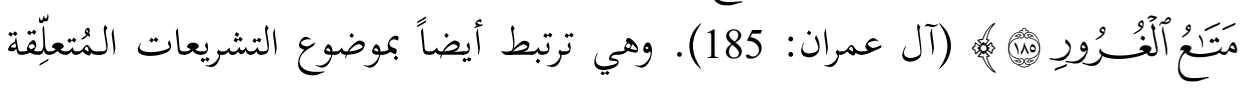

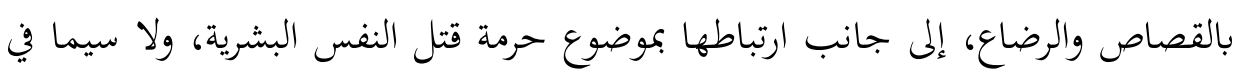

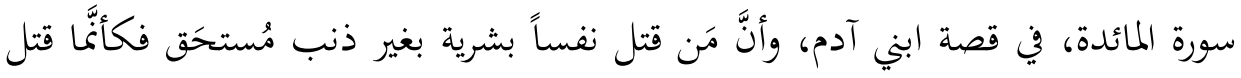
الناس كافةً.

وقد انتهت هذه القراءة للنص القرآي إلى مجموعة من الاستنتاجات، أبرزها:

32 أشار إلى ذلك بوضوح عبد الوهاب النجار في كتابه "قصص الأنبياء"، في سياق حوار الملائكة مع الله؛ إذ قال:

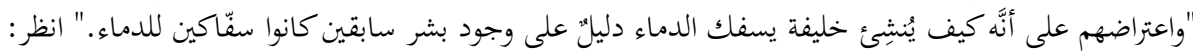

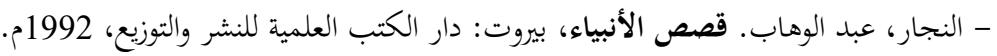

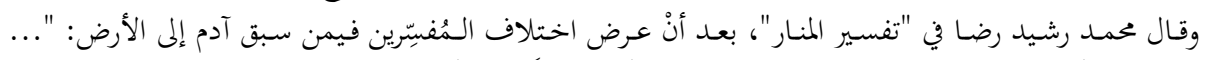

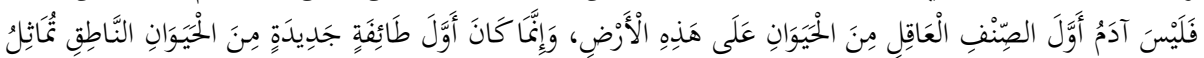

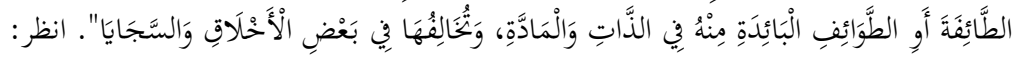

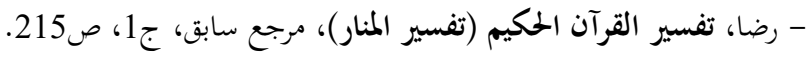




\section{أ. الاستخلاف الإنساني:}

الاستخلاف القرآني هو تصوُر صريح واضح في القرآن الكريم، يكشف عن غاية الله

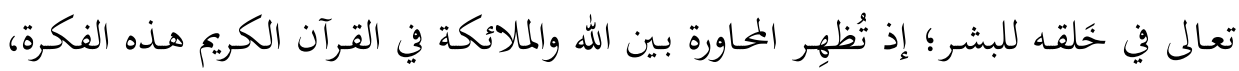

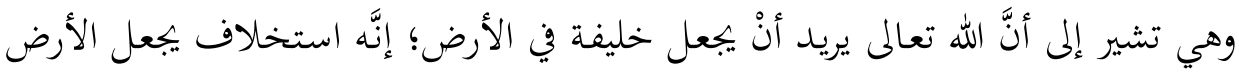

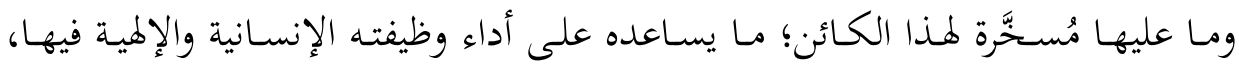

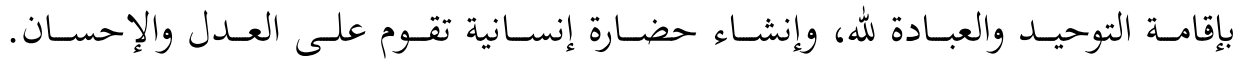

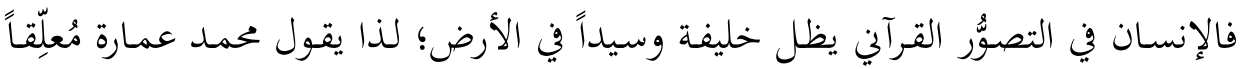

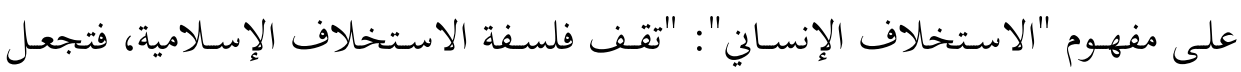

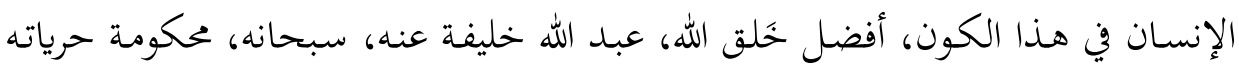
وقدراته ببنود عقد وعهد الاستخلاف؛ شريعة الله. ينقل عن محمد عبده: [الإنسان عبد

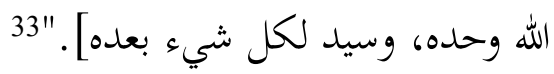

\section{ب. الاصطفاء الإنساين:}

الاصطفاء هـو أحسد مقاصــ ترقيـة الإنسـان، ومعرفة دوره في الأرض على المسـتوى الفردي والجماعي. فالاصطفاء هو اختيار إلهي لجنس البشر، بحكم الحوار الأوَّل بين الله

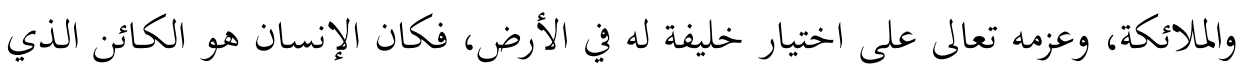

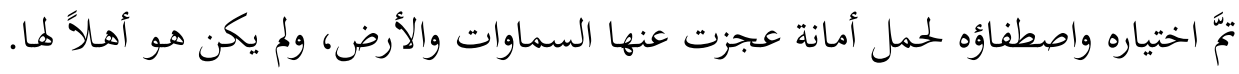

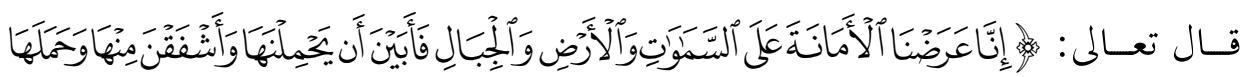

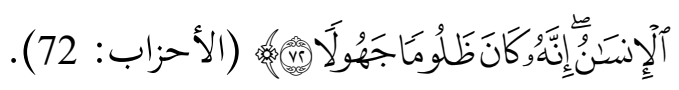

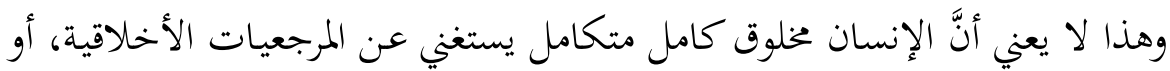

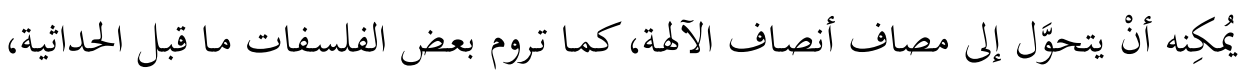

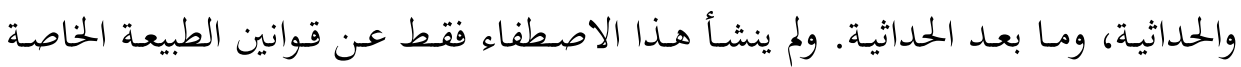

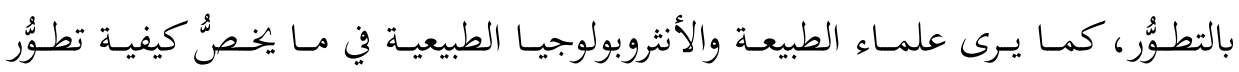




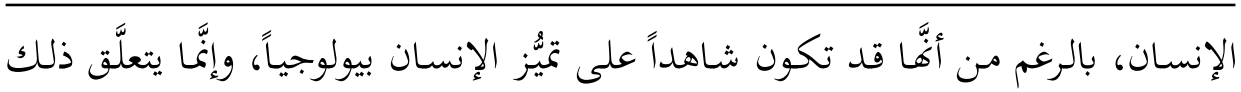
بفكرة "الاستخلاف"، وأنَّ الاصطفاء بدأ منذ اللحظة الأُولى لخذلق الإنسان الأوَّل. 34

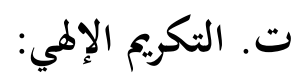

تعني فكرة "التكريم الإلهي" أنَّ الإنسان مُكرَّمَ من الإله، فلا ينبغي أنْ يُعامَل معاملةً

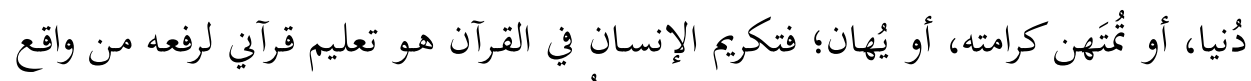

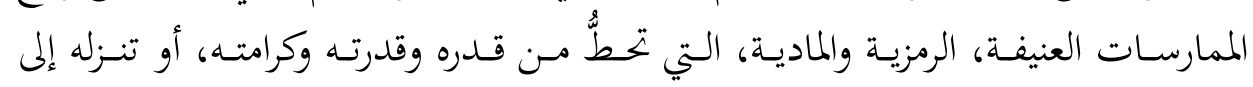

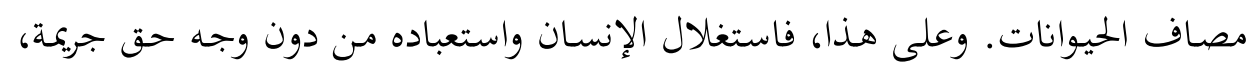
وتحريره فضيلة، وتقرير المساواة بين بني جلدته غاية.

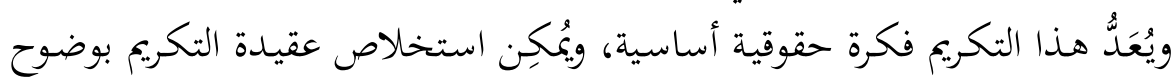

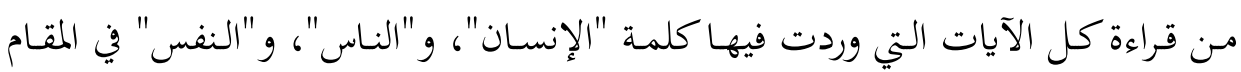
الأوَّل، إلى جانب مفردة "بني آدم" التي ورد ذكرها في الآية (70) من سورة الإسراء، التي

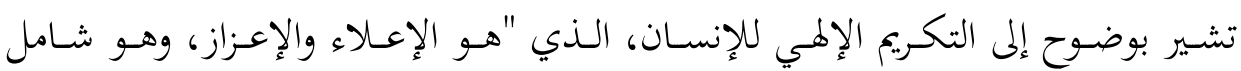

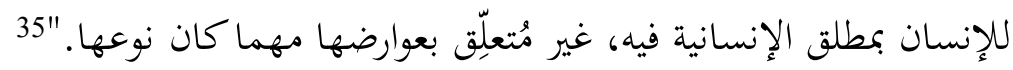

\section{ث. ثاية خَلق الإنسان:}

خَلق الله الإنسان لعبادته وامتثال أوامره واجتناب نواهيه. فالإنسان كائن مُتديِّن من

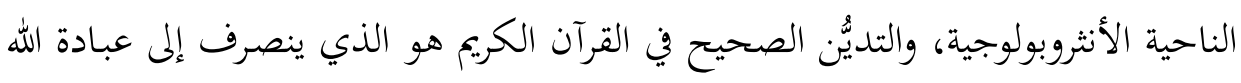

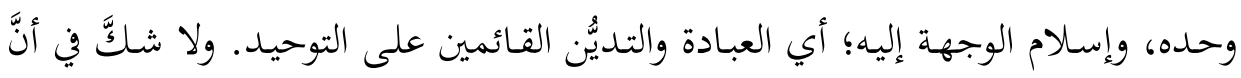

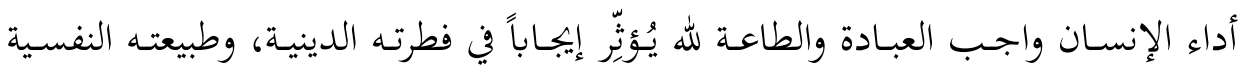

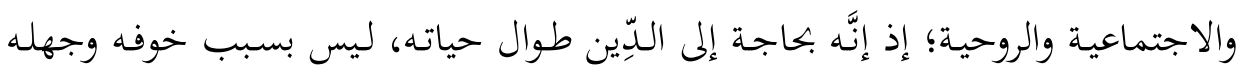

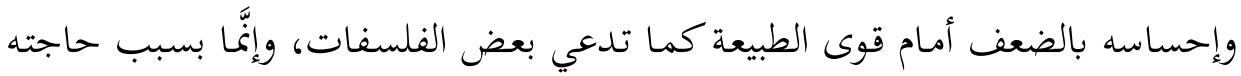

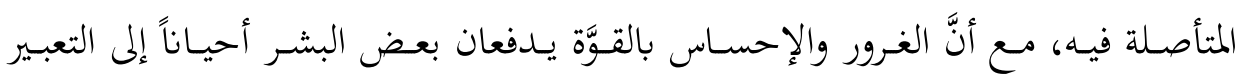
الديني عن ذلك بتأليه أنفسهم.

34 بنت الشاطئ، عائشة عبد الرحمن. مقال في الإنسان: دراسة قرآنية، القاهرة: دار المعارف، د.ت.

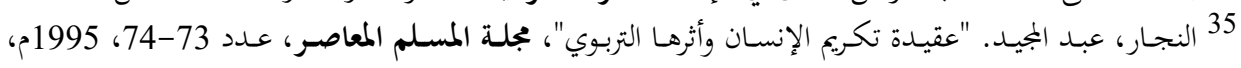


والإنسان السمُتديّن بالمفهوم الإسـامي هـو جوهر الإنسـان، ولكنَّ الفـق في مـنهج

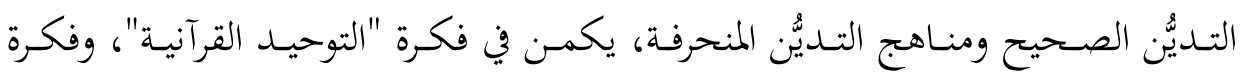
"الإسلام" الذي يعني أنْ يُسلم الإنسان مصيره وحياته لله. والغاية من خَلق الإنسان أيضاً

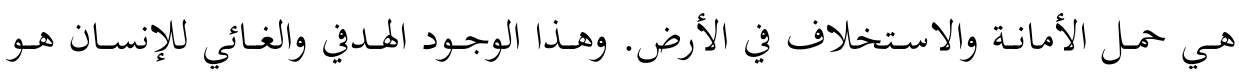

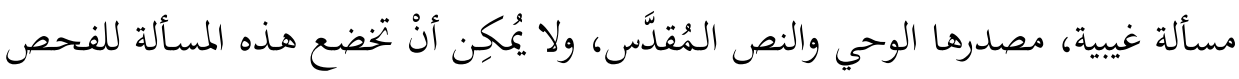

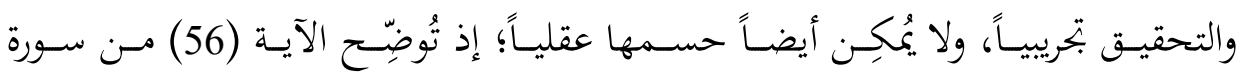

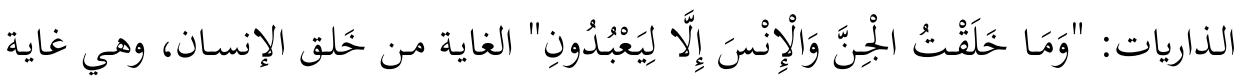

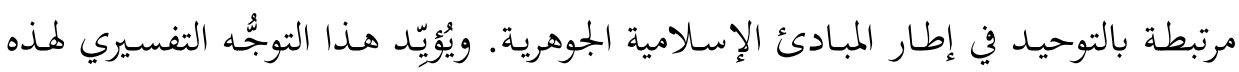
الآية من الأثر؛ ففي كتب التفسير، وردت رواية عن مجاهد تُوضِّح معنى "ليعبدون": "أي

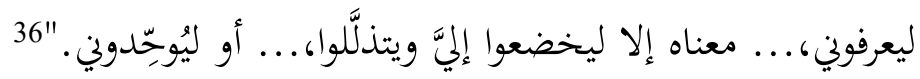

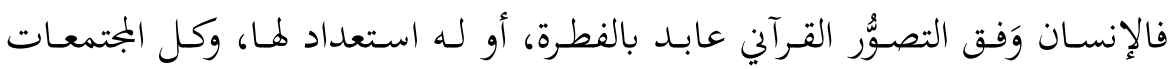
وقصص الأنبياء التي أوردها القرآن عن الأقوام السابقين تمحورت حول عبادقم المنحرفة، في مقابل العبادة الصحيحة التي دعا إليها الأنبياء. فالإنسان ما دام عابداً ومُتَّخِذاً للآلهة على الدوام، حتى لو كانت هـواه الشخصي كمـا ورد في القـرآن، ينبغي لـه -مـن باب

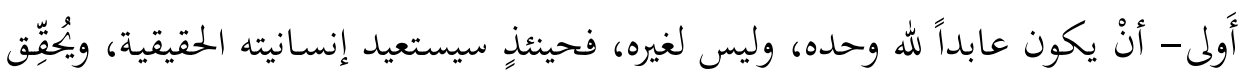
الغاية من وجوده.

\section{ج. الإنسان وخصائصه الفطرية:}

يُنظََ إلى الإنسـان في القـرآن الكريم بوصفه كائنـاً يضطرب بـين الخـير والشـر، بـين

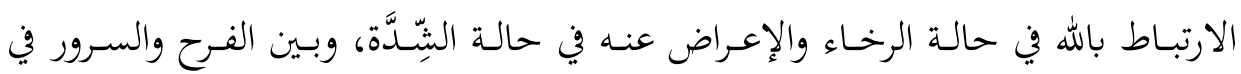

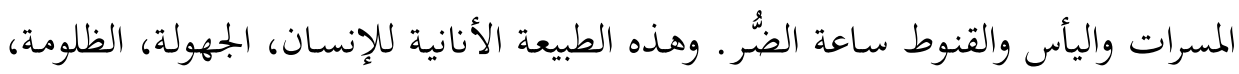

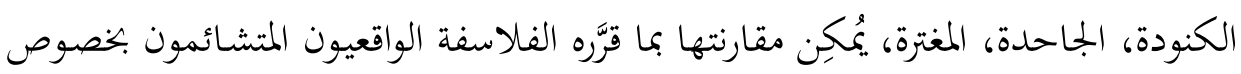

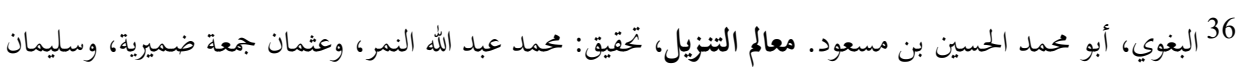

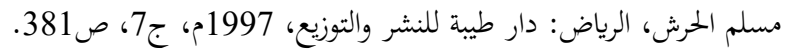


طبيعة الإنسان الشريرة الأنانية، التي جعل بعضهم منها مُنطلَقاً إلى السمو الإنساني، كما هو حال نيتشه.

وموقف الإنسان القـرآني من الفطرة هو تفعيلها في نفسه؛ حفاظاً على إنسـانيته،

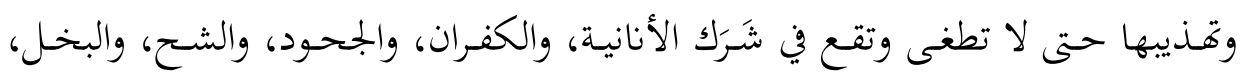
وذلك من غير حاجة إلى محاولة تبديلها، أو تبديل خَلق الله؛ فالفطرة الإنسانية هي التي تحافظ على جوهر إنسانية الإنسان. "كلما سعى الإنسان في تفعيل هذه الفطرة الإلهية،

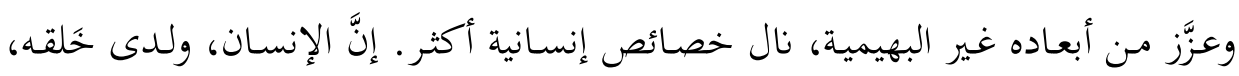

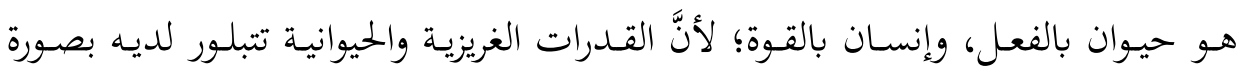

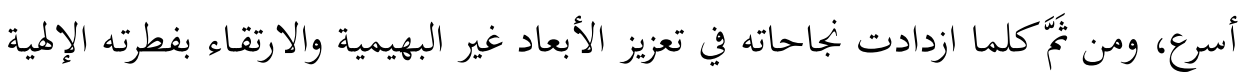

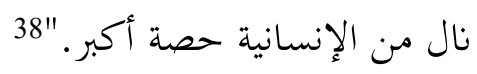

\section{ح. الناس ومجتمع الإنسان:}

الإنسان كائن اجتماعي، لا تتشكَّل خصائصه إلا عندما ينشأ في مجتمع إنساني، الإنسان

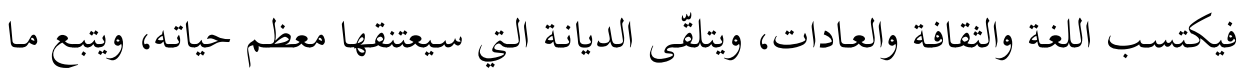

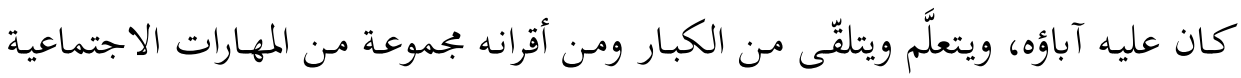
التي تساعده على العيش.

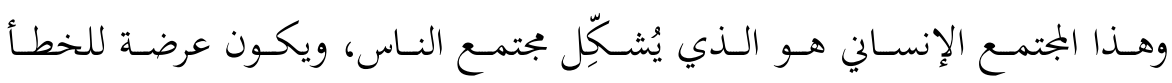

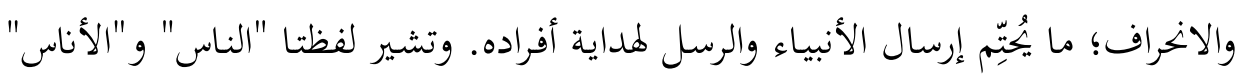

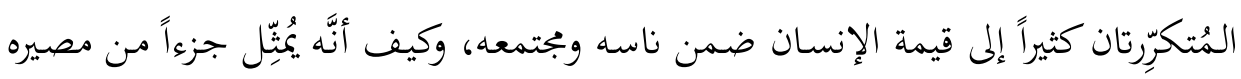

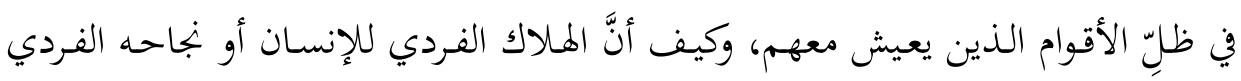
مرتبط بالسياق المجتمعي خاصته.

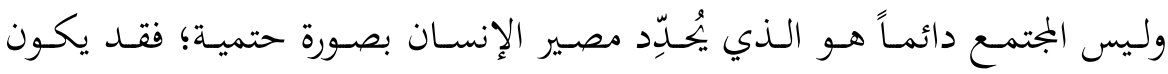

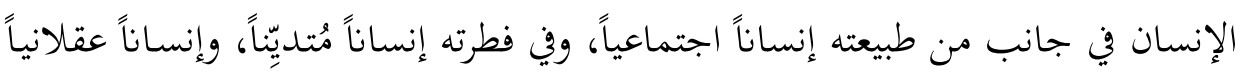

37 نيتشه، هكذا تكلم زرادشت كتاب للجميع ولغير أحد، مرجع سابق.

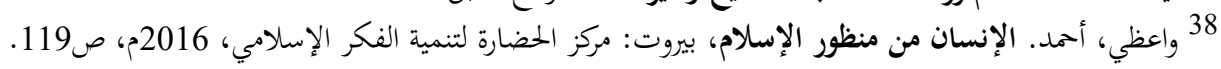


واقتصادياً. وتحاول النماذج التفسيرية النظرية الوضعية مقاربة سلوك الإنسان انطلاقاً من اختزال الإنسان نفسه في أحد أبعاد حاجاته وطبيعته. وقد أشار القرآن الكريم إلى الطبيعة

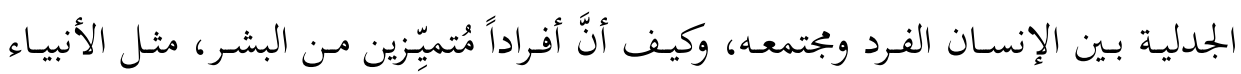

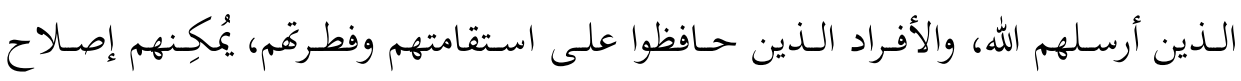

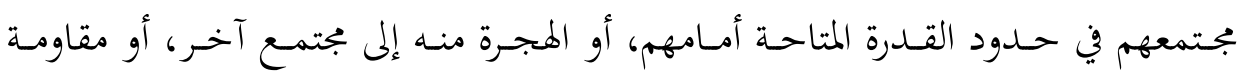
مظاهر الخلل فيه، والحفاظ على الاستقامة.

خاتمة:

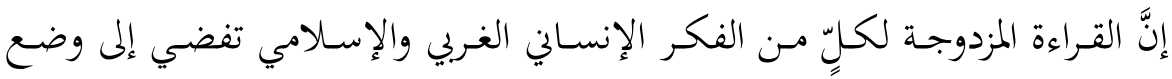

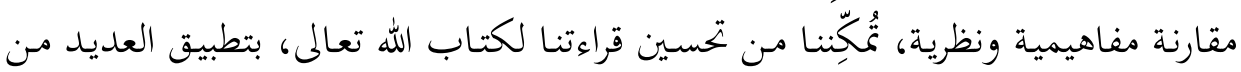

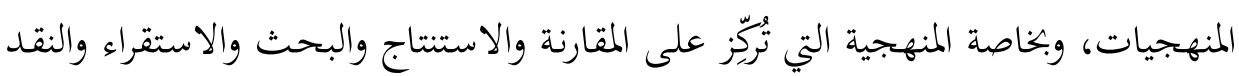

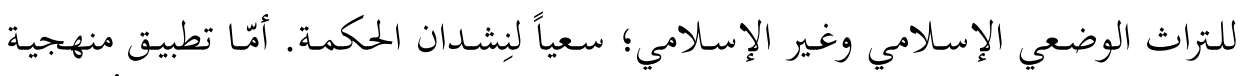

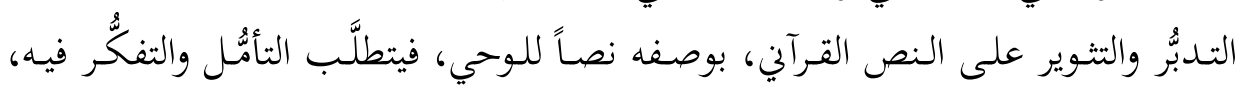

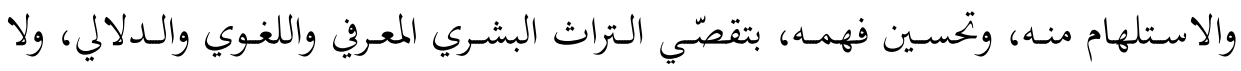

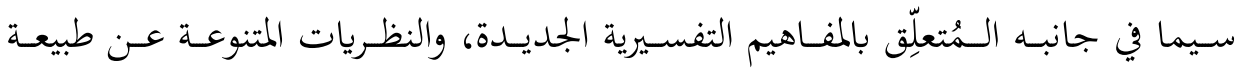

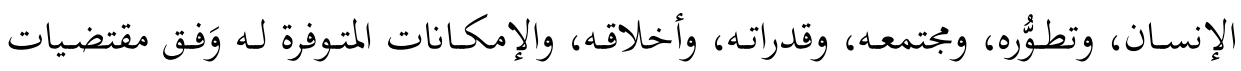

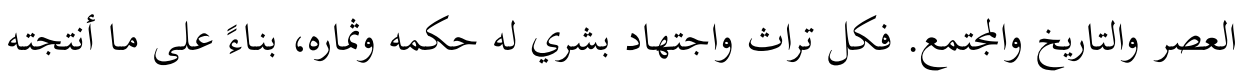

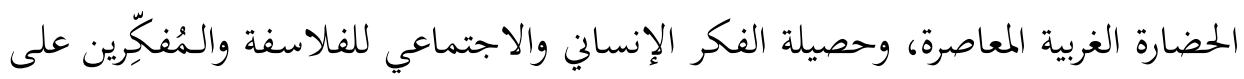
مَرِّ التاريخح.

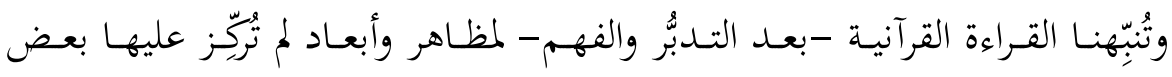

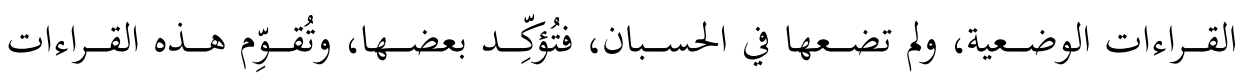

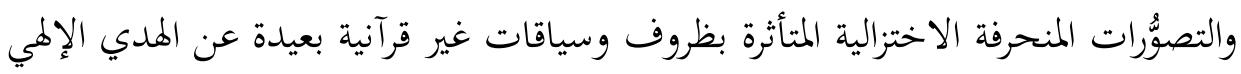

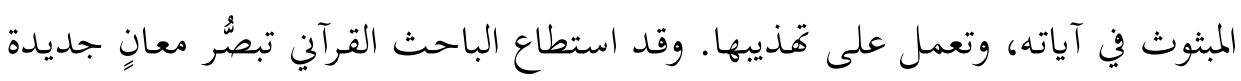
لم ترد عند المُفسِّرين السابقين؛ ما جعل القراءة أشبه بالثتوير والتحيين للفهم القرآني. 


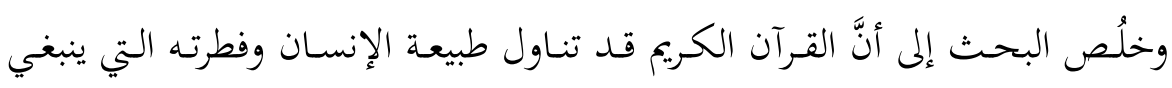

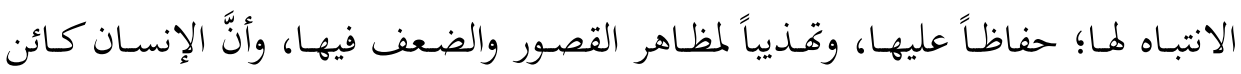

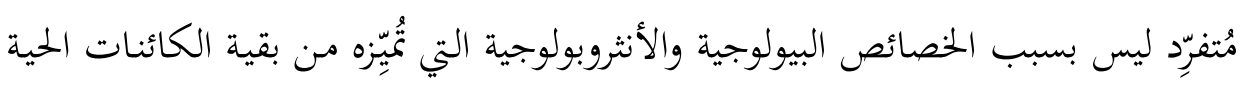

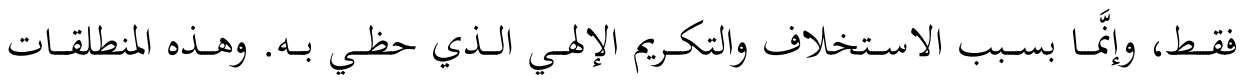

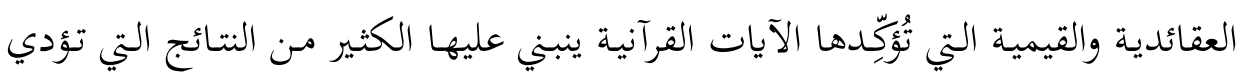

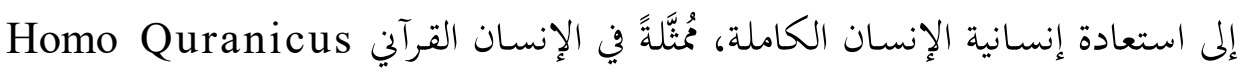
بوصفه نموذجاً للكمال الإنساني المثالي، الذي يتعيَّن على الإنسان المُسسلمِ الوصول إليه. 